\title{
Indium-Free Perovskite Solar Cells Enabled by Impermeable Tin-Oxide Electron Extraction Layers
}

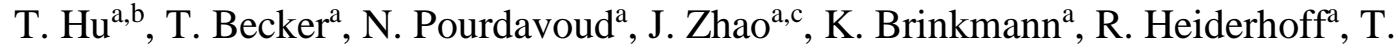

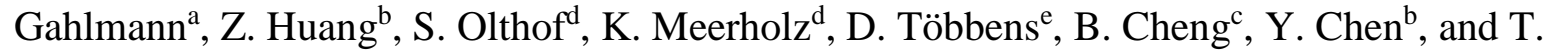 \\ Riedl $^{a^{*}}$
}

${ }^{a}$ Ting Hu, Tim Becker, Neda Pourdavoud, Jie Zhao, Kai Brinkmann, Dr. Ralf Heiderhoff, Tobias Gahlmann, Prof. Thomas Riedl Institute of Electronic Devices, University of Wuppertal, Rainer-Gruenter-Str. 21, 42119 Wuppertal, Germany

E-mail: t.riedl@uni-wuppertal.de

${ }^{b}$ Ting Hu, Zengqi Huang, Prof. Yiwang Chen

College of Chemistry/Institute of Polymers, Nanchang University, 999 Xuefu Avenue, Nanchang 330031, China

${ }^{c}$ Jie Zhao, Prof. Baochang Cheng

College of Materials Science and Engineering, Nanchang University, 999 Xuefu Avenue, Nanchang 330031, China

${ }^{d}$ Dr. Selina Olthof, Prof. Klaus Meerholz

Department of Chemistry, University of Cologne, Luxemburger Straße 116, 50939 Cologne, Germany

${ }^{e}$ Dr. Daniel Többens

Helmholtz-Zentrum Berlin für Materialien und Energie GmbH, Hahn-Meitner-Platz 1, D14109 Berlin, Germany

Since the first demonstration of organic-inorganic hybrid perovskite solar cells (PVSC), enormous attention has been devoted to this field. In the past few years, the power conversion efficiency (PCE) of PVSC saw an astonishing improvement from 3.8\% up to more than $22 \% .{ }^{[1-4]}$ Currently, PVSC are promising candidates to realize tandem cells with crystalline silicon (c-Si) and $\mathrm{Cu}(\mathrm{In}, \mathrm{Ga})(\mathrm{Se}, \mathrm{S})_{2}$ (CIGS) solar cells in an aim to unlock efficiency levels beyond $30 \%{ }^{[5-6]}$ Aside from that, semitransparent, highly efficient flexible or arbitrarily shaped PVSC are envisaged. ${ }^{[7-8]}$ For all of these applications, a sustainable concept for transparent electrodes, which can be prepared on a large area, at low costs and low 
temperatures, and which afford a conductivity and transmittance surpassing that of indiumtin-oxide (ITO), is vigorously pursued.

Among the possible ways to realize semi-transparent electrodes for thin-film photovoltaic devices, metal nanowires or ultra-thin metal layers are considered the most promising alternatives to ITO. ${ }^{[9]}$ However, for PVSCs, metals which are deposited before the perovskite layer as part of the bottom electrode are easily corroded by the precursors of the perovskite. As an example, the synthesis of the fruit-fly perovskite compound $\mathrm{CH}_{3} \mathrm{NH}_{3} \mathrm{PbI}_{3}\left(\mathrm{MAPbI}_{3}\right)$ from a solution process involves $\mathrm{PbI}_{2}$ and MAI as precursors. Typically, some post deposition annealing at temperatures in the range of $70-100^{\circ} \mathrm{C}$ is employed to finally form the $\mathrm{MAPbI}_{3}$ layer. As has been shown by various authors, chemicals like MAI severely degrade the conductivity of metal electrodes due to the formation of e.g. Ag halide species. ${ }^{[10-12]}$ In addition, the direct contact of metals like $\mathrm{Al}$ and perovskite has been shown to result in electrochemical decomposition of the perovskite, leading to realibility issues in the related devices. ${ }^{[13]}$ Gold has been identified to be more resilient against corrosion than $\mathrm{Ag},{ }^{[14]}$ but its high cost and unfavorable optical properties compromise its attractiveness for semitransparent electrodes. ${ }^{[9]}$ Alternatively, silver nanowires have been embedded in PEDOT:PSS, which obviously provided some protection. ${ }^{[15]}$ However, PEDOT:PSS has only very poor gas permeation barrier properties, leading to a limited long-term protection of the metal against halide compounds leaking out of the perovskite active layer. Han et al. and Kim et al. used zinc oxide $(\mathrm{ZnO})$ to protect the metal wires and to prevent their corrosion. ${ }^{[16-17]}$ Unfortunately, it turned out that the interface of $\mathrm{ZnO}$ based materials and organic-inorganic hybrid perovskites is thermally unstable and it has been identified as a source of perovskite decomposition. ${ }^{[18-19]}$ Aside from $\mathrm{ZnO}$, tin oxide $\left(\mathrm{SnO}_{\mathrm{x}}\right)$ has been explored as a promising electron extraction material for PVSCs. ${ }^{[20]}$ Solution processed $\mathrm{SnO}_{\mathrm{x}}$ has been considered ${ }^{[21-23]}$, but unfortunately, solution processed layers in general suffer from pin-holes and thus do not qualify as meaningful permeation barriers. ${ }^{[21,24]}$ Recently, $\mathrm{SnO}_{\mathrm{x}}$ grown by atomic layer deposition (ALD) using ozone or plasma ${ }^{[20,25]}$ has been considered as an electron extraction layer (EEL) for PVSCs. Moreover, we have shown very recently that $\mathrm{SnO}_{\mathrm{x}}$ grown by lowtemperature ALD forms extremely dense, conformal and pinhole free layers with outstanding gas permeation barrier properties and a superior chemical stability compared to $\mathrm{ZnO} \cdot{ }^{[26]}$ Most importantly, its concomitant electrical conductivity qualifies $\mathrm{SnO}_{\mathrm{x}}$ to be used as charge transport layer inside a thin-film solar cell. ${ }^{[26]}$ Therefore, we reasoned that the barrier properties of $\mathrm{SnO}_{\mathrm{x}}$ may be extremely beneficial to protect ultra-thin metal layers against the chemical attack due to the perovskite precursor species. 
In light of the above, in the present work we employ $\mathrm{SnO}_{\mathrm{x}}$ grown by $\mathrm{ALD}$ for a twofold purpose: (i) as protection layer for the ultra-thin metal layer as part of a semitransparent Infree bottom electrode and (ii) as concomitant electron extraction layer in a conventional planar PVSC. ALD in general relies on the sequential delivery of a metal-organic precursor and an oxidant. In the case of our $\mathrm{SnO}_{\mathrm{x}}$ the oxidant can be water $\left(\mathrm{H}_{2} \mathrm{O}-\mathrm{SnO}_{\mathrm{x}}\right)$, ozone (ozone$\mathrm{SnO}_{\mathrm{x}}$ ), or oxygen plasma (plasma-SnO ${ }_{\mathrm{x}}$ ). ${ }^{[27]} \mathrm{We}$ have recently shown that $\mathrm{H}_{2} \mathrm{O}-\mathrm{SnO}_{\mathrm{x}}$ states an excellent EEL for organic solar cells. ${ }^{[28-29]}$ Specifically, the $\mathrm{SnO}_{\mathrm{x}}$ based EEL mitigated issues like UV-light soaking and photo-induced shunts, which frequently occur in organic solar cells based on $\mathrm{ZnO}$ or $\mathrm{TiO}_{\mathrm{x}}$ as EELs. In principle, $\mathrm{H}_{2} \mathrm{O}$ based ALD processes are among the most widely established ones for a range of metal-oxides and they are even compatible with atmospheric processing in a roll-to-roll scheme. ${ }^{[30-31]}$ Until now, there is no report about the application of $\mathrm{H}_{2} \mathrm{O}-\mathrm{SnO}_{\mathrm{x}}$ as EEL in PVSCs, and a comparative study of $\mathrm{H}_{2} \mathrm{O}-\mathrm{SnO}_{\mathrm{x}}$, ozone$\mathrm{SnO}_{\mathrm{x}}$, and plasma-SnO ${ }_{\mathrm{x}}$ as EEL is missing. More importantly, the concomitant functionality of the $\mathrm{SnO}_{\mathrm{x}}$ as permeation barrier to shield thin metal layers against the halide compounds used in the perovskite deposition process has not been envisaged, as of yet. As such, our report is the first demonstration of semitransparent bottom electrodes for PVSCs using ultrathin $\mathrm{Ag}$ and $\mathrm{Cu}$ layers protected by a $\mathrm{SnO}_{\mathrm{x}}$ permeation barrier. Beyond our successful case study, these results pave a general way towards perovskite solar cells incorporating indiumfree transparent bottom electrodes based on corrosion sensitive metals.

Table 1 Device characteristics of cells based on ozone-SnO $\mathrm{S}_{\mathrm{x}}$, plasma- $\mathrm{SnO}_{\mathrm{x}}$, and $\mathrm{H}_{2} \mathrm{O}-\mathrm{SnO}_{\mathrm{x}}$ measured in forward and reverse direction with a scan rate of $100 \mathrm{mV} / \mathrm{s}$. Mean values and standard deviation were obtained from 20 devices for each EEL configuration. The values in parenthesis state the respective maximum values. Note, all current density values have been corrected for spectral mismatch of our AM1.5 light source by using EQE data.

\begin{tabular}{lccccc}
\hline $\begin{array}{c}\mathrm{EEL} \\
\mathrm{SnO}_{\mathrm{x}}\end{array}$ & $\begin{array}{c}J / V \\
\text { sweep } \\
\text { direction }\end{array}$ & $\begin{array}{c}J_{\mathrm{sc}} \\
{\left[\mathrm{mA} \mathrm{cm}{ }^{-2}\right]}\end{array}$ & $\begin{array}{c}V_{\mathrm{oc}} \\
{[\mathrm{V}]}\end{array}$ & $\begin{array}{c}\text { FF } \\
{[\%]}\end{array}$ & $\begin{array}{c}\text { PCE } \\
{[\%]}\end{array}$ \\
\hline \multirow{2}{*}{ ozone } & Reverse & $20.1 \pm 0.2(20.5)$ & $1.17 \pm 0.01(1.186)$ & $59 \pm 3(67)$ & $13.9 \pm 0.7(15.3)$ \\
& Forward & $19.8 \pm 0.2(20.3)$ & $1.17 \pm 0.01(1.186)$ & $63 \pm 2(68)$ & $14.5 \pm 0.4(15.4)$ \\
\hline \multirow{2}{*}{ plasma } & Reverse & $20.0 \pm 0.3(20.5)$ & $1.12 \pm 0.03(1.164)$ & $60 \pm 2(63)$ & $13.3 \pm 0.6(14.6)$ \\
& Forward & $19.8 \pm 0.3(20.3)$ & $1.11 \pm 0.03(1.164)$ & $57 \pm 2(61)$ & $12.5 \pm 0.5(13.6)$ \\
\hline \multirow{2}{*}{$\mathrm{H}_{2} \mathrm{O}$} & Reverse & $19.8 \pm 0.6(20.9)$ & $1.04 \pm 0.06(1.110)$ & $51 \pm 4(59)$ & $10.6 \pm 1.2(12.7)$ \\
& Forward & $19.0 \pm 0.7(20.4)$ & $1.03 \pm 0.07(1.100)$ & $43 \pm 3(48)$ & $8.4 \pm 1(9.8)$ \\
\hline
\end{tabular}



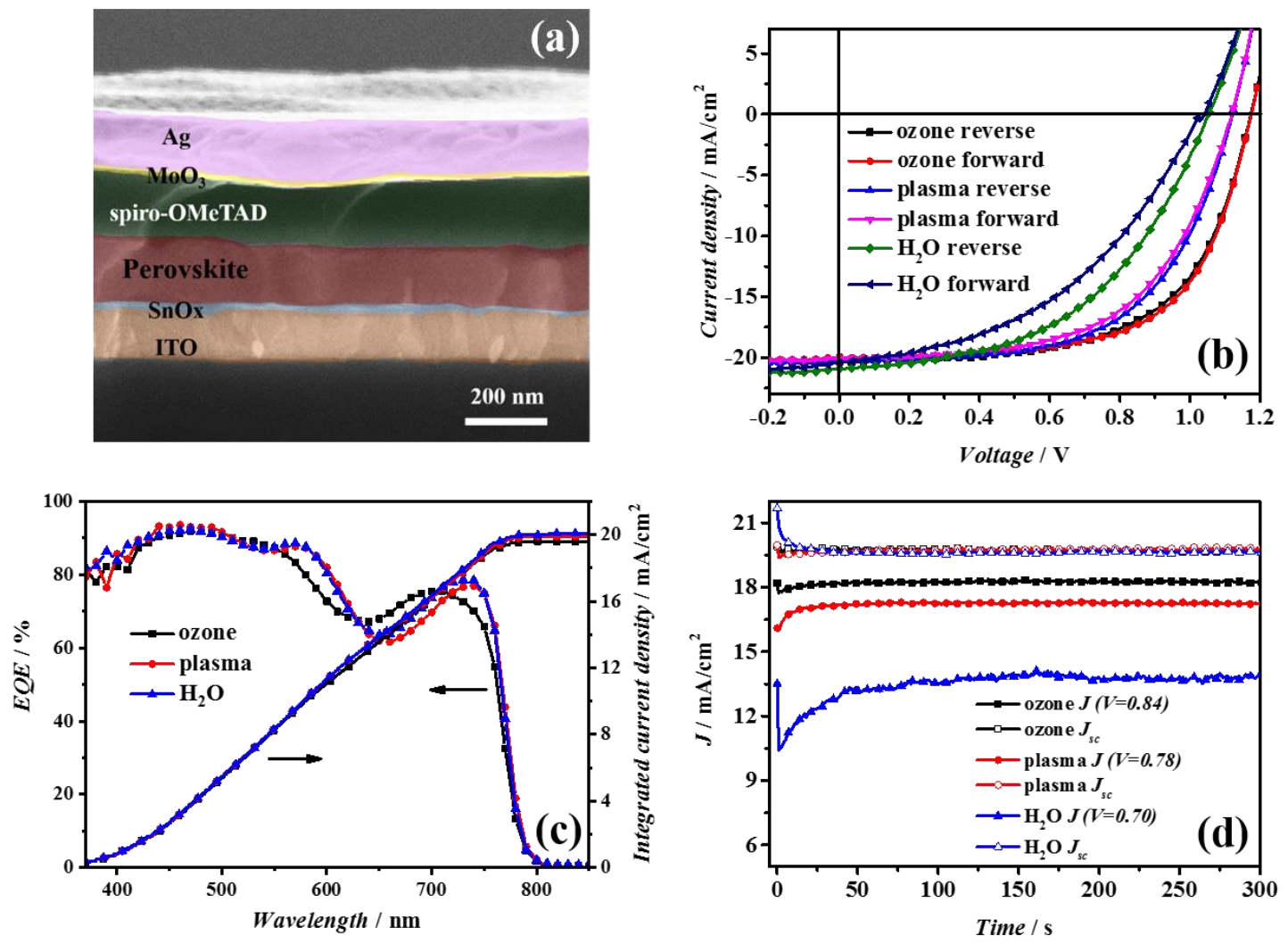

Figure 1 Cross-sectional scanning electron micrograph of the planar PVSC that we use to evaluate the functionality of $\mathrm{SnO}_{\mathrm{x}}$ as EEL. (a). Current-voltage characteristics of PVSC based on ozone- $\mathrm{SnO}_{\mathrm{x}}$, plasma-SnO ${ }_{\mathrm{x}}$, and $\mathrm{H}_{2} \mathrm{O}-\mathrm{SnO}_{\mathrm{x}}$, measured in forward and reverse direction with a scan rate of $100 \mathrm{mV} / \mathrm{s}$ (b). External quantum efficiency (EQE) together with EQE based integrated $J_{\text {sc }}$ for devices based on ozone-SnO , plasma- $\mathrm{SnO}_{\mathrm{x}}$, and $\mathrm{H}_{2} \mathrm{O}-\mathrm{SnO}_{\mathrm{x}}$ (c). Current density vs. time under short circuit (open symbols) and maximum power point (filled symbols) conditions (d). Note, all current density values have been corrected for spectral mismatch of our AM1.5 light source by using EQE data.

The cross-sectional scanning electron micrograph of the conventional PVSC stack used to evaluate the functionality of $\mathrm{SnO}_{\mathrm{x}}$ as EEL is displayed in Figure 1a. The $\mathrm{SnO}_{\mathrm{x}}$ layers in this set of samples were grown by ALD at $100^{\circ} \mathrm{C}$ and they had a thickness of $20 \mathrm{~nm}$. The perovskite layer was deposited by a one-step solution method with a thickness of approximately $180 \mathrm{~nm}$. Details can be found in the experimental section. The current-voltage $(J-V)$ characteristics of devices based on different $\mathrm{SnO}_{\mathrm{x}}$ layers are illustrated in Figure $\mathbf{1 b}$. The corresponding performance parameters are listed in Table 1. A graphical representation of the device statistics is shown in Figure S1. The devices based on ozone-SnO $\mathrm{O}_{\mathrm{x}}$ exhibit the best performance with a remarkably high $V_{o c}$ of up to $1.186 \mathrm{~V}$ (average: $1.17 \mathrm{~V}$ ) and a maximum PCE of $15.4 \%$ (average $14.5 \%$ in reverse sweep and $15.3 \%$ as derived from a stabilized current density in the maximum power point (MPP) (Figure 1d)). Note, with a 
typical bandgap of $1.55 \mathrm{eV}$ for the $\mathrm{MAPbI}_{3}$ we derive a voltage loss, i.e. $E_{\mathrm{g}} / q-V_{\mathrm{oc}}$, of only $0.36 \mathrm{~V}$, which is among the lowest values reported for PVSCs and rivals that of commercial silicon cells. ${ }^{[32]}$ For the devices based on plasma-SnO ${ }_{x}$, the $V_{\text {oc }}$ is about $1.11 \mathrm{~V}$ with a PCE of $13.5 \%$ (derived from a stabilized current density in the maximum power point). We want to note, that these devices show a negligible hysteresis. In stark contrast, the devices based on $\mathrm{H}_{2} \mathrm{O}-\mathrm{SnO}_{\mathrm{x}}$ show a significant hysteresis behavior with a substantially lower $V_{\mathrm{oc}}$ of only 1.04 $\mathrm{V}$ and an average PCE of $10.6 \%$ for the reverse and $8.4 \%$ for the forward scan. The external quantum efficiency (EQE) spectra together with the integrated $J_{\text {sc }}$ for devices based on ozone$\mathrm{SnO}_{\mathrm{x}}$, plasma-SnO $\mathrm{x}$, and $\mathrm{H}_{2} \mathrm{O}-\mathrm{SnO}_{\mathrm{x}}$ are shown in Figure 1c. Figure 1d shows the temporal dependence of the current density at $0 \mathrm{~V}\left(J_{\mathrm{sc}}\right)$ and at the maximum power point $\left(J_{\mathrm{MPP}}\right)$ under constant illumination. Both $J_{\mathrm{sc}}$ and $J_{\mathrm{MPP}}$ are stable for all the devices over the time of the experiment. Current-voltage scans at various voltage sweep rates for the devices can be found in the supporting information (Figure S2).

In an attempt to unravel the reasons for the strikingly different device characteristics depending on the choice of oxidant in the ALD process of the $\mathrm{SnO}_{\mathrm{x}}$ EEL, we initially checked the layer morphology of the different $\mathrm{SnO}_{\mathrm{x}}$ variants on ITO by using scanning electron microscopy (SEM) (Figure S3). It turns out that all our $\mathrm{SnO}_{\mathrm{x}}$ layers show a similar surface structure. As such, the layer morphology does give a hint to the reasons underlying the different device characteristics. Furthermore, we analyzed the crystal structure of the perovskite layers deposited on top of the different $\mathrm{SnO}_{\mathrm{x}}$ EEL. X-ray diffraction (XRD) patterns of the respective perovskite films are displayed in Figure 2. Apparently, the crystallinity of the perovskite layers does not depend on the oxidant used for the deposition of the $\mathrm{SnO}_{\mathrm{x}}$ layer. Some small $\mathrm{XRD}$ signal due to $\mathrm{PbI}_{2}$ is found in all samples. In order to illustrate the morphology of the perovskite on different $\mathrm{SnO}_{\mathrm{x}}, \mathrm{SEM}$ and atomic force microscopy (AFM) have been performed, as presented in Figure S4 and S5, revealing no obvious change in crystal size or surface structure. Moreover, contact angle measurements showed the same wettability of the three $\mathrm{SnO}_{\mathrm{x}}$ films for the perovskite ink (Figure S6). Taken together, the morphological characterization of the perovskite does not point to reasons for the differences in the device characteristics. It can therefore be assumed that the variations in performance are related to changes in the respective interfacial electronic structure. 


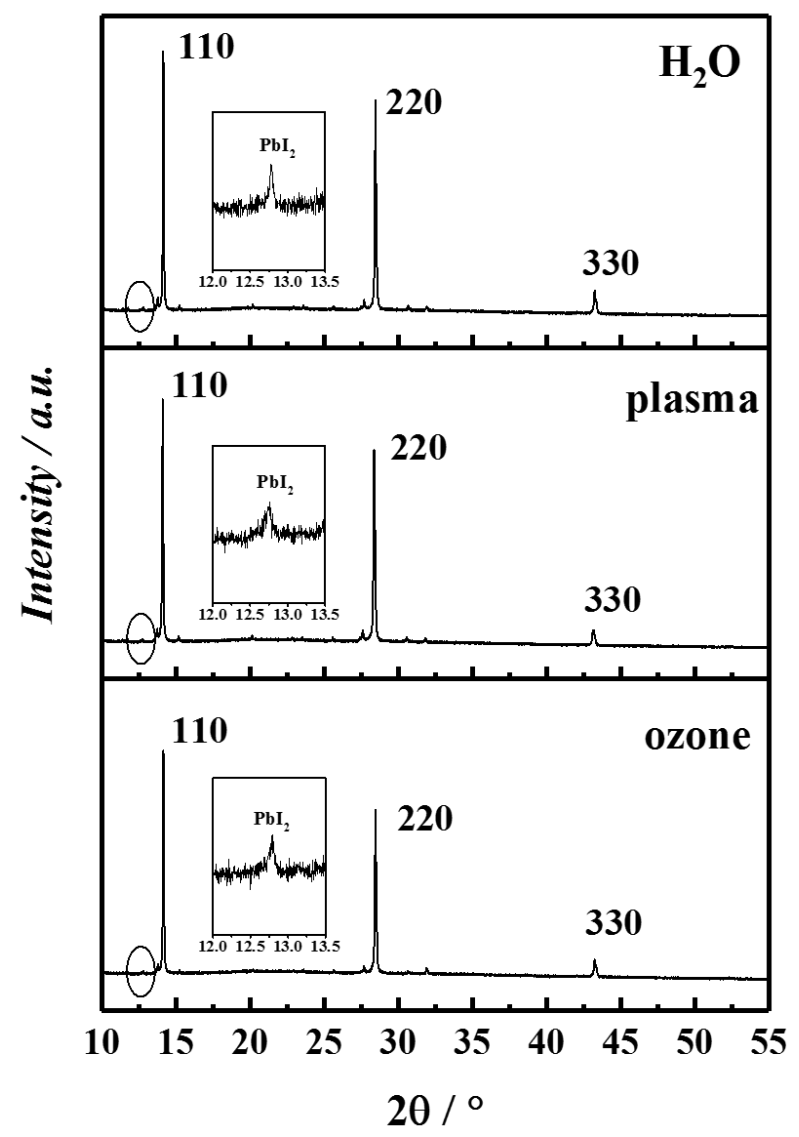

Figure $2 \mathrm{X}$-ray diffractograms of $180 \mathrm{~nm}$ thick perovskite films deposited on a glass $/ \mathrm{SnO}_{\mathrm{x}}$ substrate, using ozone-SnO $\mathrm{x}_{\mathrm{x}}$, plasma- $\mathrm{SnO}_{\mathrm{x}}$, and $\mathrm{H}_{2} \mathrm{O}-\mathrm{SnO}_{\mathrm{x}}$, respectively. The insets show magnifications of the $\mathrm{PbI}_{2}$ peak region.
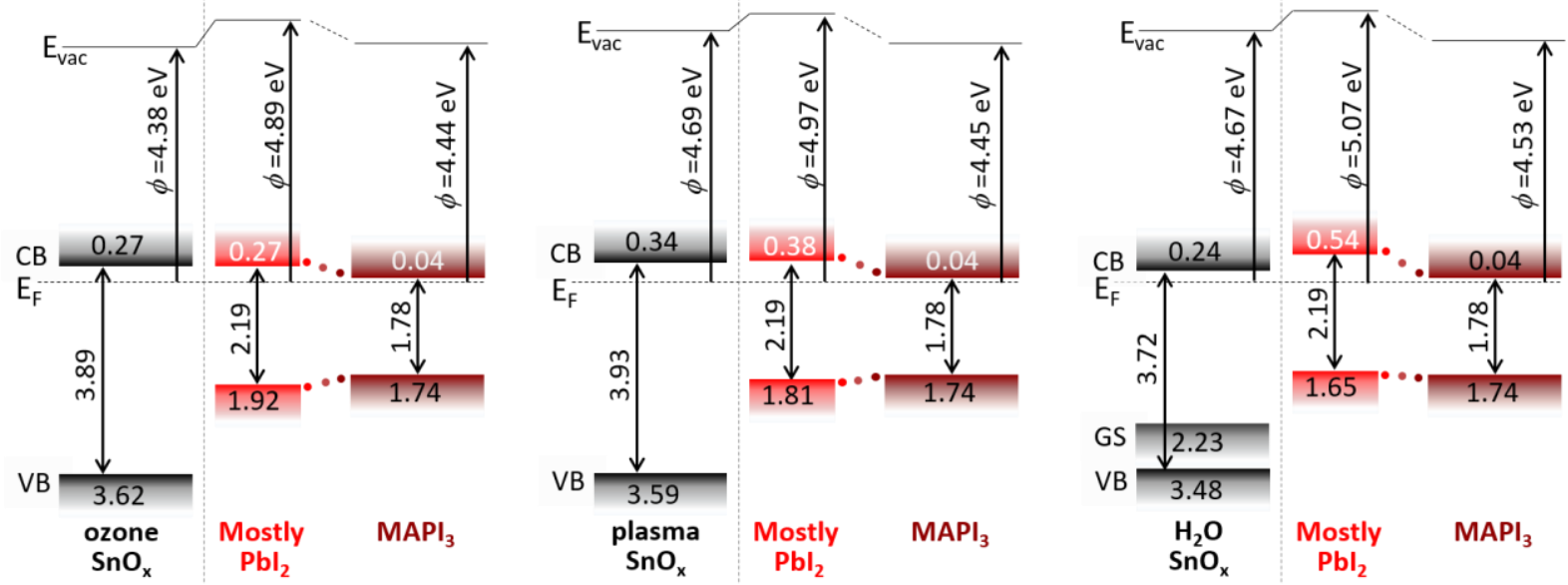

Figure 3 Electronic structure of the different $\mathrm{SnO}_{\mathrm{x}}$ variants in their pristine state and of a thin and thick (bulk-like) $\mathrm{MAPbI}_{3}$ layer deposited on top of them. The energy level positions were determined by UPS and IPES measurements of the as prepared layers (Figure S7). The conduction band $(\mathrm{CB})$ position of the $\mathrm{PbI}_{2}$-like rich interface layer was derived from the UPS/IPES measurement of a separately prepared $\mathrm{PbI}_{2}$ film (Figure S8). Abbreviations: $E_{\mathrm{vac}}$ vacuum level, $E_{\mathrm{F}}$ Fermi energy, $\phi$ work function. The values written at the VB and CB mark their distance from the Fermi energy. 
A detailed analysis of the $\mathrm{SnO}_{\mathrm{x}}$ layers and their respective interfaces was performed, using Kelvin Probe (KP), UV and X-ray photoelectron spectroscopy (UPS, XPS) as well as inverse photoelectron spectroscopy (IPES). From the Kelvin Probe analysis we determined a work function $\phi$ of $4.12 \mathrm{eV}$ for ozone- $\mathrm{SnO}_{\mathrm{x}}, 4.32 \mathrm{eV}$ for plasma- $\mathrm{SnO}_{\mathrm{x}}$, and $4.3 \mathrm{eV}$ for $\mathrm{H}_{2} \mathrm{O}-\mathrm{SnO}_{\mathrm{x}}$. In UPS, a similar trend albeit with somewhat shifted values was confirmed (4.38 eV for ozone$\mathrm{SnO}_{\mathrm{x}}, 4.69 \mathrm{eV}$ for plasma-SnO ${ }_{\mathrm{x}}$, and $4.67 \mathrm{eV}$ for $\mathrm{H}_{2} \mathrm{O}-\mathrm{SnO}_{\mathrm{x}}$ ) (see Figure 3).

Aside from the electronic properties of the $\mathrm{SnO}_{\mathrm{x}}$ layers alone, the electronic structure at their interface to the adjacent perovskite is of importance. To this end, we deposited thin $(<10 \mathrm{~nm})$ as well as thick $(180 \mathrm{~nm})$ perovskite layers on top of $\mathrm{SnO}_{\mathrm{x}}$ surfaces and again performed photoelectron spectroscopy.

Interestingly, the valence band spectra of the thin perovskite layers did not show the typical shape of the density of states known for $\mathrm{MAPbI}_{3}$ (Figure S8a), but rather resembled that of $\mathrm{PbI}_{2}$, which has a very distinct state approximately $2 \mathrm{eV}$ below the Fermi level (cf. ref. ${ }^{\text {[33] }}$ and the $\mathrm{PbI}_{2}$ spectrum in Figure S8a). In agreement to this finding, the XPS spectra reveal a substantial deficiency of nitrogen and carbon species in the thin perovskite layers on the ozone and plasma $\mathrm{SnO}_{\mathrm{x}}$ samples (Figure S9c,d), which likewise suggests the presence of $\mathrm{PbI}_{2}$ and therefore supports the UPS findings. The formation of a $\mathrm{PbI}_{2}$ interfacial layer has earlier been observed between $\mathrm{TiO}_{2}$ and $\mathrm{MAPbI}_{3}{ }^{\left[{ }^{[3]}\right.}$ as well as between ITO and $\mathrm{MAPbI}_{3}{ }^{\left[{ }^{[3]}\right.}$

Curiously, on the $\mathrm{H}_{2} \mathrm{O}$ sample, there is significantly more $\mathrm{N}$ and $\mathrm{C}$ signal in the thin perovskite layer; however, as the UPS spectra is indistinguishable from the other two samples, we still suggest the same presence of $\mathrm{PbI}_{2}$ with some additional MAI bound to the interface. Note, the XRD data also showed the presence of $\mathrm{PbI}_{2}$, albeit without providing the information that it is located at the interface to the EEL. Thus, we conducted synchrotron grazing incidence wide angle $\mathrm{x}$-ray scattering (GIWAXS) on a thin $\mathrm{MAPbI}_{3}$ layer (thickness $<10 \mathrm{~nm}$ ) deposited on our $\mathrm{SnO}_{\mathrm{x}}$ under inert atmosphere (Figure S10). We took particular care that the $\mathrm{MAPbI}_{3}$ was not exposed to ambient air during handling the samples and during the measurement in order to rule out moisture induced degradation of the $\mathrm{MAPbI}_{3}$ (please see Experimental section for details). As can be seen in Figure S10, the GIWAXS pattern is dominated by a signal due to $\mathrm{PbI}_{2}$ with only a minor contribution of $\mathrm{MAPbI}_{3}$ remaining. In contrast, GIWAXS on thick layers repeats the results of normal XRD. Obviously, the ratio of $\mathrm{PbI}_{2}$ to $\mathrm{MAPbI}_{3}$ correlates with the volume of interface relative to the total volume of the layer. This strongly corroborates the formation of $\mathrm{PbI}_{2}$ at the interface of $\mathrm{MAPbI}_{3}$ and $\mathrm{SnO}_{\mathrm{x}}$. Taken together, our results indicate that the interface between the $\mathrm{SnO}_{\mathrm{x}}$ EELs and the 
perovskite comprises a $\mathrm{PbI}_{2}$ interfacial layer which has an electronic bandgap of $2.19 \mathrm{eV}$ as derived from UPS/IPES (Figure S8b); earlier reports found a comparable band gap of $\mathrm{PbI}_{2}$ of $2.3 \mathrm{eV} \cdot{ }^{[36]}$

For the thick $\mathrm{MAPbI}_{3}$ layers, the UPS measurements show the typical $\mathrm{MAPbI}_{3}$ features ${ }^{\text {[37-38] }}$ (Figure S8a), and the results of UPS and IPES (Figure S8b) provide a bandgap of $1.78 \mathrm{eV}$, which is larger than the value typically derived from optical data in the range of 1.55$1.6 \mathrm{eV} \cdot{ }^{[39]}$ As the exciton binding energy in $\mathrm{MAPbI}_{3}$ is known to be small it cannot be the reason for the difference between the electronic and optical band gap. Rather, this discrepancy can be attributed to uncertainties in the determination of the onset positions of the DOS of the $\mathrm{MAPbI}_{3}$ perovskite in PES data. It has been shown that the VB onset derived from a linear representation of the UPS spectra, as is done here, results in an underestimation of the small DOS close to the VB onset. The small DOS close to the VB onset can be better pronounced by using a semi-logarithmic plot of the VB spectra. ${ }^{[40]}$ As the proper interpretation of such a semi-logarithmic plot requires the fitting of the measurement to density functional theory data and comes with some ambiguity we favor using the linear data and focus the argumentation along the lines of the relative shifts of the VB/CB levels when comparing the alignment on the three different EELs, as shown in Figure 3.

Very remarkably, we encounter varying degrees of energy steps in the $\mathrm{CB}$ between $\mathrm{MAPbI}_{3}$ and the $\mathrm{PbI}_{2}$ interface layer which are $0.23 \mathrm{eV}$ (for ozone-SnO${ }_{\mathrm{x}}$ ), $0.34 \mathrm{eV}$ (plasma-SnO $\mathrm{x}_{\mathrm{x}}$ ), and $0.5 \mathrm{eV}\left(\mathrm{H}_{2} \mathrm{O}-\mathrm{SnO}_{\mathrm{x}}\right)$, respectively. As the energetic position of the thick perovskite layer is identical for all three samples, the differences in energy step are due to varying positions of the $\mathrm{CB}$ position of the $\mathrm{PbI}_{2}$ interface layer. This can partly be attributed to the differences in $\mathrm{SnO}_{\mathrm{x}}$ work function but more importantly the interface dipoles between $\mathrm{SnO}_{\mathrm{x}}$ and $\mathrm{PbI}_{2}$ do vary. The underlying microscopic reason for this effect is difficult to identify, but it could be due to slight differences in the composition of this $\mathrm{PbI}_{2}$ interface layer, making it e.g. more or less n-type in nature. Note that no change in the position of the Sn3d core level peaks is found upon thin perovskite coverage (Figure S9e), meaning that band bending in the $\mathrm{SnO}_{\mathrm{x}}$ is not affected by the deposition of the perovskite, so we infer no significant charge transfer upon contact formation. To shed more light onto the energetic line-up between $\mathrm{SnO}_{\mathrm{x}}$ and $\mathrm{PbI}_{2}$, we conducted a series of UPS measurements of $\mathrm{PbI}_{2}$ at varied thicknesses, which was thermally evaporated onto the respective $\mathrm{SnO}_{\mathrm{x}}$ layer with nanometer control (Figure S11). When comparing the electronic structure of the thermally evaporated $\mathrm{PbI}_{2}$ films to that of the thin solution processed $\mathrm{MAPbI}_{3}$ on top of the different $\mathrm{SnO}_{\mathrm{x}}$ EELs (Figure 3) it can be estimated that the thickness of the interface induced $\mathrm{PbI}_{2}$ layer is between $1.5 \mathrm{~nm}$ and $3 \mathrm{~nm}$ as here both 
the electronic alignment and the shape of the DOS show excellent agreement. The notable difference in the interfacial dipole discussed for the thin $\mathrm{MAPbI}_{3}$ on top of the different $\mathrm{SnO}_{\mathrm{x}}$ layers is in agreement with the respective interface dipole found for the thermally evaporated $\mathrm{PbI}_{2}$. In addition, almost no band bending in the $\mathrm{PbI}_{2}$ is found in the case of $\mathrm{PbI}_{2}$ on top of ozone-SnO ${ }_{x}$, while there is a significant upward band bending in the $\mathrm{PbI}_{2}$ toward the interface with the $\mathrm{H}_{2} \mathrm{O}-\mathrm{SnO}_{\mathrm{x}}$, which amounts to an electron extraction barrier of $360 \mathrm{meV}$. For the $3 \mathrm{~nm}$ thick $\mathrm{PbI}_{2}$ layers the surface electronic structure is almost the same on top of the different $\mathrm{SnO}_{\mathrm{x}}$ EEL.

In light of the energetic line-up data, we now discuss the dark $J$ - $V$ characteristics of our PVSC based on the different $\mathrm{SnO}_{\mathrm{x}}$ EELs (Figure S12a). All devices show a clear rectifying behavior. However, the reverse current density of the $\mathrm{H}_{2} \mathrm{O}-\mathrm{SnO}_{\mathrm{x}}$ devices is about an order of magnitude higher than that of the plasma-SnO $\mathrm{x}_{\mathrm{x}}$ and ozone-SnO $\mathrm{x}$ based cells. This can be explained in view of the UPS/IPES data (Figure S11), where a $0.5 \mathrm{eV}$ lower barrier for hole injection between the CB-edge of $\mathrm{SnO}_{\mathrm{x}}$ and the VB-edge of the $\mathrm{PbI}_{2}$ has been found in the case of $\mathrm{H}_{2} \mathrm{O}-\mathrm{SnO}_{\mathrm{x}}$ compared to ozone-SnO . For plasma-SnO $\mathrm{S}_{\mathrm{x}}$, the barrier for hole injection is only about $0.26 \mathrm{eV}$ lower compared to ozone- $\mathrm{SnO}_{\mathrm{x}}$. At low forward bias (i.e. $<0.4 \mathrm{~V}$ ), the $\mathrm{H}_{2} \mathrm{O}-$ $\mathrm{SnO}_{\mathrm{x}}$ devices show the highest current density, which is indicative of shunting. ${ }^{[41]}$ In earlier work, a universal space charge limited current model for leakage currents in various thin-film solar cells has been presented. ${ }^{[42]}$ Among the physical origins an inhomogeneity in the electrodes, i.e. pin-holes, roughness, local variation of the work-function, has been discussed. First, we expect that the efficiency of hole-injection via the spiro-MeOTAD/MoO $3 / \mathrm{Ag}$ is the same for all the devices. We do not have any morphological indication (Figure S3) that would hint to an elevated shunting due to increased roughness of the $\mathrm{H}_{2} \mathrm{O}-\mathrm{SnO}_{x}$. Furthermore, we can rule out pin-holes, as the $\mathrm{SnO}_{\mathrm{x}}$ was deposited by $\mathrm{ALD}$, which is known for dense layers that are pin-hole free and conformal. Indeed, we have previously shown than these ALD grown $\mathrm{SnO}_{\mathrm{x}}$ layers yield outstanding gas permeation barriers, which would not be possible in the presence of pin-holes. ${ }^{[26,43]}$ A possible origin of the elevated leakage current could be a substantially less effective hole blocking character of the $\mathrm{H}_{2} \mathrm{O}-\mathrm{SnO}_{\mathrm{x}}$ EEL compared to that based on ozone-SnO $\mathrm{x}_{\mathrm{x}}$. As discussed below, the presence of the gap states found in $\mathrm{H}_{2} \mathrm{O}-\mathrm{SnO}_{\mathrm{x}}$ may compromise its hole-blocking properties and open up an additional transport channel for holes. In addition, local variations of the electronic structure at the interface may occur, but would not be detected by UPS due to a lack of lateral resolution. Scanning Kelvin probe or scanning thermal microscopy may be techniques to further assess these shunts in future work. 
In an attempt to better understand the effect of the observed extraction barrier in the $\mathrm{CB}$ on the electron extraction form the perovskite (see Figure 3), we studied a set of electron-only devices. To this end, the solar cell layer sequence has been modified by using PCBM/Ca/Al on top of the perovskite (see inset of Figure S12b). The PCBM/Ca/Al assembly allows for the injection of electrons into the perovskite and we can study their extraction via the bottom electrode from the corresponding $J-V$ characteristics (Figure S12b). In the device based on ozone- $\mathrm{SnO}_{\mathrm{x}}$, we find the highest electron-only current, indicating the most efficient electron extraction from the perovskite. In contrast, the device with $\mathrm{H}_{2} \mathrm{O}-\mathrm{SnO}_{\mathrm{x}}$ presents an about two orders of magnitude smaller electron current, while the current in the plasma-SnO $\mathrm{x}_{\mathrm{x}}$ device is in between. This order corresponds nicely to the increasing electronic barrier between the $\mathrm{PbI}_{2}$ and the $\mathrm{MAPbI}_{3}$, which is smallest for the ozone- $\mathrm{SnO}_{\mathrm{x}}$ and largest for $\mathrm{H}_{2} \mathrm{O}-\mathrm{SnO}_{\mathrm{x}}$ (see above). Earlier reports in the field of organic solar cells have unambiguously demonstrated a lowered $F F$ if charge extraction barriers are present. ${ }^{[44-46]}$ At the same time, parasitic recombination of charges which are not efficiently extracted will lower the $\mathrm{V}_{\text {oc. }}{ }^{[4]}$ The role of the gap states in the $\mathrm{H}_{2} \mathrm{O}-\mathrm{SnO}_{\mathrm{x}}$ EELs, which were found $E_{\mathrm{GS}}=2.23 \mathrm{eV}$ below the Fermi level on the device performance is not fully clear, as of yet. The energetic proximity of these filled states in the EEL to the $\mathrm{VB}$ of the adjacent $\mathrm{PbI}_{2}\left(E_{\mathrm{GS}}-E_{\mathrm{VB}, \mathrm{PbI} 2}=0.58 \mathrm{eV}\right)$ could represent a recombination channel for photo-generated holes. As a result, the electron selectivity of the $\mathrm{H}_{2} \mathrm{O}-\mathrm{SnO}_{\mathrm{x}}$ EEL would be compromised compared to the other $\mathrm{SnO}_{\mathrm{x}}$ EELs. A low electrode selectivity due to surface recombination has been discussed in detail by Reinhardt et al. ${ }^{[47]}$ In this framework, a loss of selectivity has been clearly identified to cause a loss of $V_{\text {oc }}$ and $F F$, similar to our findings for the cells based on $\mathrm{H}_{2} \mathrm{O}-\mathrm{SnO}_{\mathrm{x}}$.

So far we studied the interface properties of $\mathrm{SnO}_{\mathrm{x}}$ as EEL in PVSCs, whereas now we consider its concomitant permeation barrier functionality as a key building block of an ITOfree bottom electrode based on an ultra-thin Ag layer. As outlined in the introduction, for any suitable transparent bottom electrode in PVSC, damage due to the deposition of the perovskite on top must be avoided. The alternative bottom electrode envisaged in this work is based on an ultra-thin Ag layer. Initially, we evaluated the formation and resilience of the metal layer. To this end, we have prepared a $7 \mathrm{~nm}$ thin Ag layer by sputtering on top of a glass substrate, which resulted a sheet resistance $\left(R_{\mathrm{sh}}\right)$ of $18 \Omega / \mathrm{sq}$. As can be seen in Table 2 , after deposition of the perovskite on top, the Ag layer entirely lost its conductivity. Note, for the deposition of the perovskite on top of the Ag electrode, we applied the standard protocol as detailed in the experimental section. Briefly, the perovskite precursor solution was spin coated followed by 
thermal annealing on a hot plate at $100^{\circ} \mathrm{C}$. Already after 30 s of annealing, the sheet resistance increased by more than three orders of magnitude. After 1 minute no conductivity could be detected anymore. Our finding is in line with previous reports which found the degradation of Ag due to a chemical reaction with halide compounds, like MAI. ${ }^{[1]}$

To prevent this corrosive effect, we use protective layer of $\mathrm{SnO}_{\mathrm{x}}$ on top of the ultra-thin $\mathrm{Ag}$. It has to be noted that the Ag layer was destroyed in the ALD process in the case ozone-SnO $\mathrm{O}_{\mathrm{x}}$ or plasma-SnO ${ }_{x}$ was deposited on top of the Ag. On the contrary, $\mathrm{H}_{2} \mathrm{O}-\mathrm{SnO}_{\mathrm{x}}$ could be deposited on top of the Ag layer without notable change of $R_{\mathrm{sh}}$. As can be seen in Table 2, a $20 \mathrm{~nm}$ thin $\mathrm{H}_{2} \mathrm{O}-\mathrm{SnO}_{\mathrm{x}}$ layer already provided good protection against the corrosion due to the perovskite precursors. In view of our above discussion of various $\mathrm{SnO}_{\mathrm{x}}$ as EELs in the PVSC, ozone$\mathrm{SnO}_{\mathrm{x}}$ would be the preferred EEL adjacent to the perovskite, which is why we decided to use a bi-layered EEL of $\mathrm{H}_{2} \mathrm{O}-\mathrm{SnO}_{\mathrm{x}} /$ ozone-SnO $\mathrm{Sn}_{\mathrm{x}}$ on top of the Ag. Moreover, we identified a better wetting of the $\mathrm{Ag}$ layer on top of the $\mathrm{SnO}_{\mathrm{x}}$ (sample $\mathrm{H}_{2} \mathrm{O}-\mathrm{SnO}_{\mathrm{x}} / \mathrm{Ag} / \mathrm{H}_{2} \mathrm{O}-\mathrm{SnO}_{\mathrm{x}}(13 \Omega / \mathrm{sq})$ ) compared to the deposition on glass (sample Glass/Ag/ $\mathrm{H}_{2} \mathrm{O}-\mathrm{SnO}_{\mathrm{x}}(19 \Omega / \mathrm{sq})$ ). Similar substrate effects, which affect the percolation behavior of ultra-thin metal layers have been reported for $\mathrm{Ag}$ and $\mathrm{Au}$ on $\mathrm{ZnO}, \mathrm{ZnS}$ and other materials. ${ }^{[9]}$ For the realization of a semitransparent bottom electrode, we therefore consider a sandwich structure with of $\mathrm{H}_{2} \mathrm{O}$ $\mathrm{SnO}_{\mathrm{x}} / \mathrm{Ag} / \mathrm{H}_{2} \mathrm{O}-\mathrm{SnO}_{\mathrm{x}} /$ ozone- $\mathrm{SnO}_{\mathrm{x}}$ with a very low $R_{\mathrm{sh}}$ of $11 \Omega / \mathrm{sq}$, which is at par with ITO. Most importantly, its $R_{\text {sh }}$ remained essentially unaltered after deposition of the perovskite on top (Table 2).

Table 2 Sheet resistance $\left(R_{\mathrm{sh}}\right)$ for various transparent electrodes based on a $7 \mathrm{~nm}$ thick layer of Ag with and without perovskite on top.

\begin{tabular}{|c|c|}
\hline Layer sequence on glass substrate & $R_{\text {sh }}[\Omega /$ sq. $]$ \\
\hline $\mathrm{Ag}$ & 18 \\
\hline $\mathrm{Ag} /$ perovskite & not conductive \\
\hline $\mathrm{Ag} / \mathrm{H}_{2} \mathrm{O}-\mathrm{SnO}_{\mathrm{x}}$ & 19 \\
\hline $\mathrm{Ag} / \mathrm{H}_{2} \mathrm{O}-\mathrm{SnO}_{\mathrm{x}} /$ perovskite & 26 \\
\hline $\mathrm{Ag} / \mathrm{H}_{2} \mathrm{O}-\mathrm{SnO}_{\mathrm{x}} /$ ozone-SnO ${ }_{\mathrm{x}}$ & 25 \\
\hline $\mathrm{Ag} / \mathrm{H}_{2} \mathrm{O}-\mathrm{SnO}_{\mathrm{x}} /$ ozone- $\mathrm{SnO}_{\mathrm{x}} /$ perovskite & 31 \\
\hline $\mathrm{H}_{2} \mathrm{O}-\mathrm{SnO}_{\mathrm{x}} / \mathrm{Ag} / \mathrm{H}_{2} \mathrm{O}-\mathrm{SnO}_{\mathrm{x}}$ & 13 \\
\hline $\mathrm{H}_{2} \mathrm{O}-\mathrm{SnO}_{\mathrm{x}} / \mathrm{Ag} / \mathrm{H}_{2} \mathrm{O}-\mathrm{SnO}_{\mathrm{x}} /$ perovskite & 19 \\
\hline $\mathrm{H}_{2} \mathrm{O}-\mathrm{SnO}_{\mathrm{x}} / \mathrm{Ag} / \mathrm{H}_{2} \mathrm{O}-\mathrm{SnO}_{\mathrm{x}} /$ ozone- $\mathrm{SnO}_{\mathrm{x}}$ & 11 \\
\hline $\mathrm{H}_{2} \mathrm{O}-\mathrm{SnO}_{\mathrm{x}} / \mathrm{Ag} / \mathrm{H}_{2} \mathrm{O}-\mathrm{SnO}_{\mathrm{x}} /$ ozone- $\mathrm{SnO}_{\mathrm{x}} /$ perovskite & 12 \\
\hline ITO (commercial), reference & 12 \\
\hline
\end{tabular}




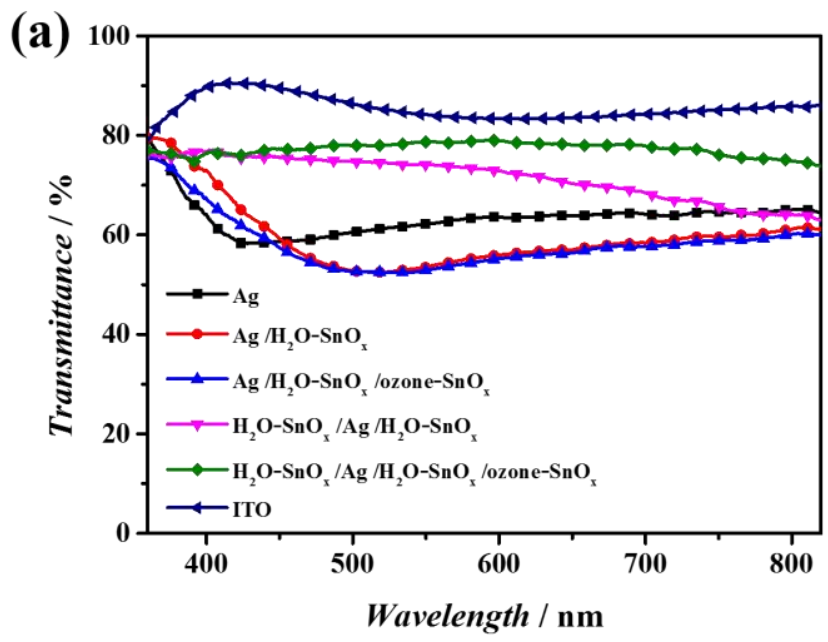

(b)

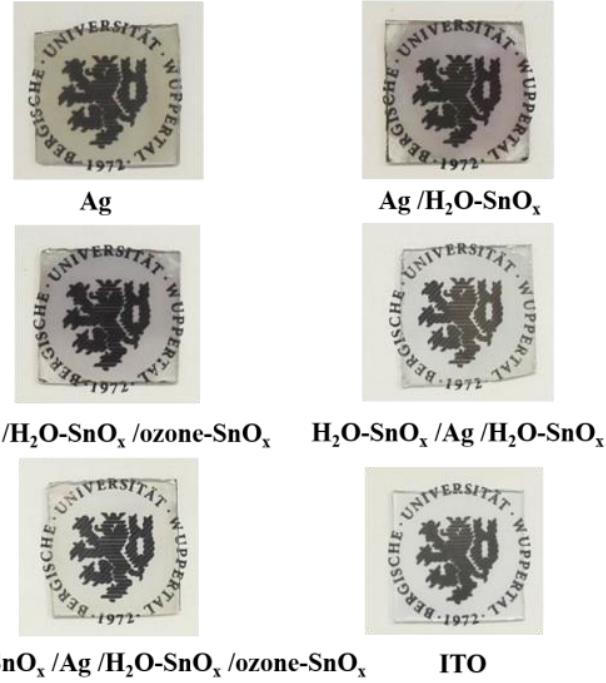

Figure 4 Optical transmission spectra (a) and photographs (b) of different $\mathrm{Ag}$ and $\mathrm{SnO}_{\mathrm{x}}$ based electrodes on glass compared to commercially available ITO on glass.

Optical transmission spectra of the electrodes are shown in Figure 4. For the samples, where the Ag layer has been directly deposited on the glass substrate, the spectra show an overall low transmittance and a characteristic V-shape with a spectral minimum around $420 \mathrm{~nm}$. This $\mathrm{V}$-shape has previously been associated with a predominant island formation of the Ag. ${ }^{[48]}$ Upon subsequent coating with a thin $\mathrm{H}_{2} \mathrm{O}-\mathrm{SnO}_{\mathrm{x}}$ layer the position of the minimum in the transmission shows a red-shift due the increased dielectric constant of the surrounding of the Ag particles, which spectrally shifts the plasmonic resonance to longer wavelength. ${ }^{[49]}$ In contrast, there is no V-shape in the transmission spectra when the Ag is deposited on top of $\mathrm{H}_{2} \mathrm{O}-\mathrm{SnO}_{\mathrm{x}}$, which is indicative of a significantly improved wetting of the Ag layer and a preferred formation of a more percolated $\mathrm{Ag}$ layer. This is in agreement with a lower $R_{\mathrm{sh}}$ of these layers. Upon careful optical impedance matching (using optical transfer matrix simulation with SETFOS ${ }^{\mathrm{TM}}$ ), a sandwich structure $\mathrm{H}_{2} \mathrm{O}-\mathrm{SnO}_{\mathrm{x}} / \mathrm{Ag} / \mathrm{H}_{2} \mathrm{O}-\mathrm{SnO}_{\mathrm{x}} /$ ozone- $\mathrm{SnO}_{\mathrm{x}}$ has been designed for optimum optical transmittance of about $\sim 80 \%$ in the visible spectral region. The associated Haacke figure of merit $\left(T_{\mathrm{av}}{ }^{10} / R_{\mathrm{sh}}\right)=9 \times 10^{-3} \Omega^{-1}$ is comparable to other $\mathrm{Ag}$ based semitransparent electrodes reported. ${ }^{[9]}$

Ultimately, the transparent electrode $\mathrm{H}_{2} \mathrm{O}-\mathrm{SnO}_{\mathrm{x}} / \mathrm{Ag} / \mathrm{H}_{2} \mathrm{O}-\mathrm{SnO}_{\mathrm{x}} /$ ozone- $\mathrm{SnO}_{\mathrm{x}}$ was applied in our PVSCs to replace ITO (Figure 5a). J-V characteristics of the device based on $\mathrm{H}_{2} \mathrm{O}-\mathrm{SnO}_{\mathrm{x}}$ $/ \mathrm{Ag} / \mathrm{H}_{2} \mathrm{O}-\mathrm{SnO}_{\mathrm{x}} /$ ozone-SnO $\mathrm{Sn}_{\mathrm{x}}$ measured in forward and reverse direction are shown in Figure 5b. The resulting device achieved a PCE of $10.2 \%$ at reverse scan and $11.0 \%$ at forward scan. 
The statistics of 15 devices is shown in Table S1 and Figure S13. A PCE of 10\% has been derived from the stabilized current density in the maximum power point (MPP) (Figure S14)). The $\mathrm{J}_{\mathrm{sc}}$ of the ITO based cells is about $20 \%$ higher, which is attributed to the somewhat higher overall transmittance of ITO compared to the $\mathrm{SnO}_{\mathrm{x}} / \mathrm{Ag} / \mathrm{SnO}_{\mathrm{x}}$ electrode (Figure 4). For a fair comparison, it has to be stressed, that the ITO is typically processed at high temperatures $\left(\mathrm{T}>300^{\circ} \mathrm{C}\right.$ ), while our $\mathrm{SnO}_{\mathrm{x}} / \mathrm{Ag} / \mathrm{SnO}_{\mathrm{x}}$ electrode is prepared at $80^{\circ} \mathrm{C}$. A comparison of $\mathrm{MAPbI}_{3}$ perovskite cells based on non-ITO bottom electrodes is shown in Table S2. Note, in this comparison we deliberately did not consider cells based on fluorine doped tin-oxide (FTO) electrodes, which actually also would be In-free but require high temperature annealing. As of yet, the highest PCE of $16.8 \%$ for ITO-free cells has been achieved by Yoon et al. using a bottom electrode based on $\mathrm{MoO}_{3}$ decorated graphene. ${ }^{[50]}$ Following our concept of $\mathrm{SnO}_{\mathrm{x}}$ as permeation barrier to shield thin metal layers against the halide compounds used in the perovskite deposition process, there is a good prospect for even further improved efficiency levels in optimized ITO-free devices based on thin metal layers or metal grid electrodes.

(a)

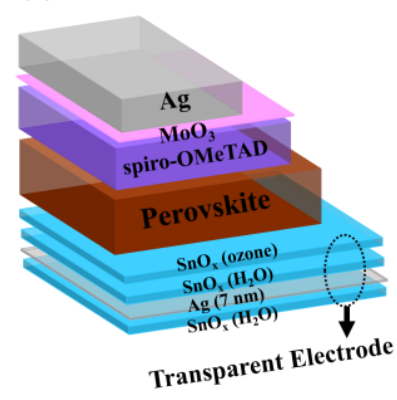

(b)

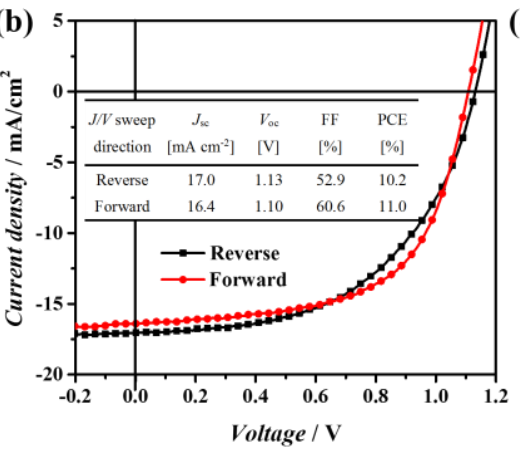

(c)

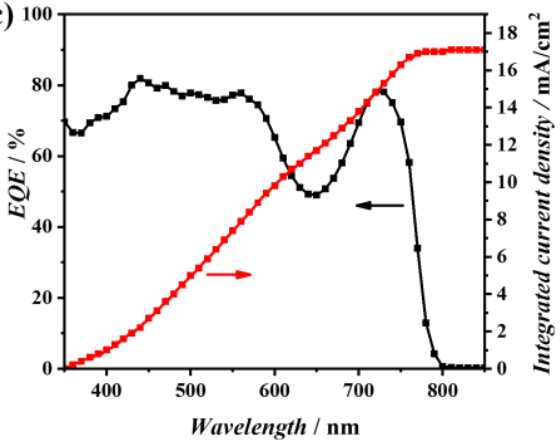

Figure 5 Layer sequence of the device based on the transparent electrode $\mathrm{H}_{2} \mathrm{O}-\mathrm{SnO}_{\mathrm{x}} / \mathrm{Ag}$ $/ \mathrm{H}_{2} \mathrm{O}-\mathrm{SnO}_{\mathrm{x}} /$ ozone-SnO $\mathrm{S}_{\mathrm{x}}$ (a), $J-\mathrm{V}$ characteristics of the solar cell measured in forward and reverse direction with a scan rate of $100 \mathrm{mV} / \mathrm{s}$ (b), the inset is the corresponding performance parameters. EQE of a representative device based on transparent electrode $\mathrm{H}_{2} \mathrm{O}-\mathrm{SnO}_{\mathrm{x}} / \mathrm{Ag}$ $/ \mathrm{H}_{2} \mathrm{O}-\mathrm{SnO}_{\mathrm{x}} /$ ozone-SnO $\mathrm{x}$ (c). Note, current density values have been corrected for spectral mismatch of our AM1.5 light source by using EQE data.

In summary, we have demonstrated a comparative study of perovskite solar cells based on $\mathrm{SnO}_{\mathrm{x}}$ electron extraction layers. Specifically $\mathrm{SnO}_{\mathrm{x}}$ prepared by ALD using water, ozone, or oxygen plasma as oxidant has been studied. The best characteristics were achieved for devices based on ozone-SnO $\mathrm{Sn}_{\mathrm{x}}$ as EEL with a stable PCE of $15.3 \%$ and a remarkably high $V_{\mathrm{oc}}$ of 1.17 V. Photoelectron spectroscopy revealed the formation of a $\mathrm{PbI}_{2}$ interfacial layer between the $\mathrm{SnO}_{\mathrm{x}}$ and the perovskite in all devices. Different interface dipoles resulted in different 
extraction barriers in the $\mathrm{CB}$ between the $\mathrm{MAPbI}_{3}$ and the $\mathrm{PbI}_{2}$ for the $\mathrm{SnO}_{\mathrm{x}}$ grown with different oxidants. Notably the barrier was the largest in case of $\mathrm{H}_{2} \mathrm{O}-\mathrm{SnO}_{\mathrm{x}}$ and the smallest in case of the ozone-SnO${ }_{x}$, which resulted in superior electron extraction when ozone-SnO $\mathrm{S}_{\mathrm{x}}$ was used. Based on this insight, we designed an ITO-free semitransparent bottom electrode based on $\mathrm{SnO}_{\mathrm{x}} / \mathrm{Ag} / \mathrm{SnO}_{\mathrm{x}}$, in which the $\mathrm{SnO}_{\mathrm{x}}$ served as electron extraction layer and its outstanding permeation barrier properties efficiently protected the ultra-thin silver layer against corrosion due to halide compounds. The resulting In-free perovskite cells achieve a PCE up to $11 \%$. The low process temperature $\left(<100^{\circ} \mathrm{C}\right)$ of the $\mathrm{SnO}_{\mathrm{x}} / \mathrm{Ag} / \mathrm{SnO}_{\mathrm{x}}$ electrode provides a clear advantage over ITO, which is typically processed at high temperatures.

\section{Experimental}

Material and preparation: Tin oxide has been prepared by atomic layer deposition in a Beneq TFS 200 system (base pressure 1.5 mbar). Tetrakis(dimethylamino)tin(IV) (TDMASn) was kept at $45{ }^{\circ} \mathrm{C}$ and water was kept at room temperature. In this paper, ozone, plasma and $\mathrm{H}_{2} \mathrm{O}$ were used as oxidants and the substrate temperature was $100{ }^{\circ} \mathrm{C}$. The growth rates for the $\mathrm{SnO}_{\mathrm{x}}$ layer at $100{ }^{\circ} \mathrm{C}$ were $1.0 \AA$ per cycle for ozone, $1.11 \AA$ per cycle for plasma and $0.88 \AA$ per cycle for $\mathrm{H}_{2} \mathrm{O}$. For semitransparent bottom electrodes of $\mathrm{SnO}_{\mathrm{x}} / \mathrm{Ag} / \mathrm{SnO} \mathrm{x}, \mathrm{SnO}_{\mathrm{x}}$ was prepared at $80{ }^{\circ} \mathrm{C}$ with water as oxidant. The growth rate was $1.06 \AA$ per cycle.

Thin Ag film was deposited by RF magnetron sputtering at a total RF-power of $50 \mathrm{~W}$ at pressures of $1.1 \times 10^{-2}$ mbar.

The perovskite solution was prepared by dissolving lead acetate trihydrate (99.999\%, SigmaAldrich) and Methylammonium Iodide ( $>98 \%$, Dyesol) in anhydrous N,NDimethylformamide at a 1:3 molar ratio with final concentrations of $\sim 42 \mathrm{wt} \%$.

The spiro-MeOTAD solution was prepared by dissolving $72.3 \mathrm{mg}$ of spiro-MeOTAD (99\%, Sigma-Aldrich), $28.8 \mu \mathrm{L}$ of 4-tert-butyl pyridine and $17.5 \mu \mathrm{L}$ of lithium bis(trifluoromethanesulfonyl) imide solution $(520 \mathrm{mg} \mathrm{Li}-\mathrm{TSFI}$ in $1 \mathrm{~mL}$ acetonitrile, SigmaAldrich,99.8\%) in $1 \mathrm{~mL}$ of chlorobenzene. The pure $\mathrm{PbI}_{2}$ (Alfa Aesar, 99.999\%) films for the UPS interface study were thermally evaporated at $330^{\circ} \mathrm{C}$ inside a vacuum chamber where the thickness was measured by quartz crystal monitors assuming a density of $6.16 \mathrm{~g} / \mathrm{cm}^{3}$.

Device fabrication: ozone- $\mathrm{SnO}_{x}$, plasma- $\mathrm{SnO}_{\mathrm{x}}$ and $\mathrm{H}_{2} \mathrm{O}-\mathrm{SnO}_{\mathrm{x}}$ were grown by ALD at $100{ }^{\circ} \mathrm{C}$ on ITO. Then the perovskite solution was spin-coated on top at $4000 \mathrm{rpm}$ for $30 \mathrm{~s}$ in a nitrogen-filled glovebox, followed by annealing at $100{ }^{\circ} \mathrm{C}$ for $10 \mathrm{~min}$. After cooling to room temperature, the hole transporting layer spiro-MeOTAD solution was spin-coated on top at $4000 \mathrm{rpm}$ for $30 \mathrm{~s}$. Finally, $8 \mathrm{~nm}$ thick $\mathrm{MoO}_{3}$ and $120 \mathrm{~nm} \mathrm{Ag}$ was deposited on top by 
evaporation in high vacuum $\left(10^{-7} \mathrm{mbar}\right)$. The active area is $3.14 \mathrm{~mm}^{2}$. For the device based on transparent electrode, the fabrication is the same and the active area is $4 \mathrm{~mm}^{2}$.

Characterization: The solar cells were characterized using a Keithley 2400-C source meter and a solar simulator ( $300 \mathrm{~W}$ Newport, AM1.5G, $100 \mathrm{~mW} \mathrm{~cm}{ }^{-2}$ ). The sheet resistance was measured with the van der Pauw method. Crystallinity of perovskite films was assessed by Xray diffraction (XRD) using a monochromatic $\mathrm{Cu}-\mathrm{K} \alpha 1,2-$ source (Philips X'Pert Pro MPD). GIWAXS data were collected at beamline KMC-2 of BESSY II, Berlin, ${ }^{[51]}$ using a wavelength of 1.5406(1) $\AA$, equivalent to $\mathrm{Cu} \mathrm{K} \alpha 1$ radiation, and a Vantec 2000 area detector. Data collection times varied, with up to $1 \mathrm{~h}$ for a single frame and up to $6 \mathrm{~h}$ for a $2 \theta$-scan over the range $10-40^{\circ}$. The sample slides were mounted in an airtight sample holder inside of a glovebox with actively controlled $\left(\mathrm{O}_{2}=2 \mathrm{ppm}\right.$, moisture $\left.<1 \mathrm{ppm}\right)$ Argon atmosphere. They were never exposed to air before or during the experiment. Measurements were done in outof-plane grazing incidence geometry in order to increase signal intensity. Both sample position and incidence angle were determined for each individual sample and are accurate within $\pm 0.01 \mathrm{~mm}$ and $\pm 0.01^{\circ}$, respectively. An incidence angle of $1^{\circ}$ was choosen for most measurements; scans of varying incidence angle up to $8^{\circ}$ done with selected samples did not reveal any different results.

The measurements of the surface potential were done with a McAllister KP6500 KelvinProbe (KP) system. Highly ordered pyrolytic graphite with a WF of $4.5 \mathrm{eV}$ was used as reference. UV photoelectron spectroscopy measurements were performed using a monochromatic VUV 5000 microwave UV source at 21.22 eV (VG Scienta) and a Phoibos 100 hemispherical analyzer (Specs). For X-ray photoelectron spectroscopy a nonmonochromatic $\mathrm{Mg} \mathrm{K} \alpha$ excitation source was used $(1252.6 \mathrm{eV})$ at a pass energy of $10 \mathrm{eV}$. The thicknesses of the layers were measured by a Dektak profilometer. The SEM studies were conducted using a Philips XL30S FEG microscope with a field emission cathode. Atomic force microscopy (AFM) height images were obtained using a MultiMode 8 (Bruker) operated in the tapping mode.

\section{Supporting Information}

Supporting Information is available from the Wiley Online Library or from the author; in this manuscript it is included as pages 19-28. 


\section{Acknowledgments}

We acknowledge the German Federal Ministry for Education and Research (Grant No.: 03EK3529E) and the Deutsche Forschungsgemeinschaft (DFG) (Grant: RI1551/4-2) for financial support. We acknowledge the Ministry of Science of the state of NRW for funding within the PeroBOOST (EFRE) project. The research leading to these results has received partial funding from the European Unions's 7th Framework Programme under Grant Agreement no. 604148 (MUJULIMA). T.H. would like to thank for financial support from the fellowship program of the China Scholarship Council.

\section{References}

[1] A. Kojima, K. Teshima, Y. Shirai, T. Miyasaka, J Am Chem Soc 2009, 131, 6050.

[2] H. Zhou, Q. Chen, G. Li, S. Luo, T.-b. Song, H.-S. Duan, Z. Hong, J. You, Y. Liu, Y. Yang, Science 2014, 345, 542.

[3] W. S. Yang, J. H. Noh, N. J. Jeon, Y. C. Kim, S. Ryu, J. Seo, S. I. Seok, Science 2015, 348, 1234.

[4] X. Li, D. Bi, C. Yi, J.-D. Décoppet, J. Luo, S. M. Zakeeruddin, A. Hagfeldt, M. Grätzel, Science 2016, 353, 58.

[5] C. D. Bailie, M. G. Christoforo, J. P. Mailoa, A. R. Bowring, E. L. Unger, W. H. Nguyen, J. Burschka, N. Pellet, J. Z. Lee, M. Gratzel, R. Noufi, T. Buonassisi, A. Salleo, M. D. McGehee, Energ Environ Sci 2015, 8, 956.

[6] F. Fu, T. Feurer, T. Jager, E. Avancini, B. Bissig, S. Yoon, S. Buecheler, A. N. Tiwari, Nat Commun 2015, 6, 8932.

[7] S. G. Hashmi, M. Ozkan, J. Halme, S. M. Zakeeruddin, J. Paltakari, M. Gratzel, P. D. Lund, Energ Environ Sci 2016, 9, 2453.

[8] X. Dai, Y. Zhang, H. Shen, Q. Luo, X. Zhao, J. Li, H. Lin, Acs Appl Mater Inter 2016, $8,4523$.

[9] K. Zilberberg, T. Riedl, Journal of Materials Chemistry A 2016, 4, 14481.

[10] Y. Kato, L. K. Ono, M. V. Lee, S. Wang, S. R. Raga, Y. Qi, Advanced Materials Interfaces 2015, 2, 1500195.

[11] C.-Y. Chang, K.-T. Lee, W.-K. Huang, H.-Y. Siao, Y.-C. Chang, Chem Mater 2015, 27, 5122.

[12] K. A. Bush, C. D. Bailie, Y. Chen, A. R. Bowring, W. Wang, W. Ma, T. Leijtens, F. Moghadam, M. D. McGehee, Adv Mater 2016, 28, 3937.

[13] L. Zhao, R. A. Kerner, Z. Xiao, Y. L. Lin, K. M. Lee, J. Schwartz, B. P. Rand, ACS Energy Letters 2016, 1, 595.

[14] C. Bao, W. Zhu, J. Yang, F. Li, S. Gu, Y. Wang, T. Yu, J. Zhu, Y. Zhou, Z. Zou, Acs Appl Mater Inter 2016, 8, 23868. 
[15] Y. Li, L. Meng, Y. Yang, G. Xu, Z. Hong, Q. Chen, J. You, G. Li, Y. Yang, Y. Li, Nat Commun 2016, 7, 10214.

[16] A. Kim, H. Lee, H. C. Kwon, H. S. Jung, N. G. Park, S. Jeong, J. Moon, Nanoscale 2016, 8, 6308.

[17] J. Han, S. Yuan, L. Liu, X. Qiu, H. Gong, X. Yang, C. Li, Y. Hao, B. Cao, Journal of Materials Chemistry A 2015, 3, 5375.

[18] J. Yang, B. D. Siempelkamp, E. Mosconi, F. De Angelis, T. L. Kelly, Chem Mater 2015, 27, 4229.

[19] Y. Cheng, Q. D. Yang, J. Xiao, Q. Xue, H. W. Li, Z. Guan, H. L. Yip, S. W. Tsang, ACS Appl Mater Interfaces 2015, 7, 19986.

[20] J. P. Correa Baena, L. Steier, W. Tress, M. Saliba, S. Neutzner, T. Matsui, F. Giordano, T. J. Jacobsson, A. R. Srimath Kandada, S. M. Zakeeruddin, A. Petrozza, A. Abate, M. K. Nazeeruddin, M. Grätzel, A. Hagfeldt, Energy Environ. Sci. 2015, 8, 2928.

[21] W. Ke, D. Zhao, A. J. Cimaroli, C. R. Grice, P. Qin, Q. Liu, L. Xiong, Y. Yan, G. Fang, J. Mater. Chem. A 2015, 3, 24163.

[22] W. Ke, G. Fang, Q. Liu, L. Xiong, P. Qin, H. Tao, J. Wang, H. Lei, B. Li, J. Wan, G. Yang, Y. Yan, J Am Chem Soc 2015, 137, 6730.

[23] Q. Jiang, L. Zhang, H. Wang, X. Yang, J. Meng, H. Liu, Z. Yin, J. Wu, X. Zhang, J. You, Nature Energy 2016, 2, 16177.

[24] Q. Dong, Y. Shi, K. Wang, Y. Li, S. Wang, H. Zhang, Y. Xing, Y. Du, X. Bai, T. Ma, J. Phys. Chem. C 2015, 119, 10212.

[25] C. Wang, D. Zhao, C. R. Grice, W. Liao, Y. Yu, A. Cimaroli, N. Shrestha, P. J. Roland, J. Chen, Z. Yu, P. Liu, N. Cheng, R. J. Ellingson, X. Zhao, Y. Yan, J. Mater. Chem. A 2016, 4, 12080 .

[26] A. Behrendt, C. Friedenberger, T. Gahlmann, S. Trost, T. Becker, K. Zilberberg, A. Polywka, P. Görrn, T. Riedl, Adv Mater 2015, 27, 5961.

[27] A. Behrendt, C. Friedenberger, T. Gahlmann, S. Trost, T. Becker, K. Zilberberg, A. Polywka, P. Gorrn, T. Riedl, Adv Mater 2015, 27, 5961.

[28] S. Trost, T. Becker, A. Polywka, P. Görrn, M. F. Oszajca, N. A. Luechinger, D. Rogalla, M. Weidner, P. Reckers, T. Mayer, T. Riedl, Advanced Energy Materials 2016.

[29] S. Trost, A. Behrendt, T. Becker, A. Polywka, P. Görrn, T. Riedl, Advanced Energy Materials 2015, 5, 1500277.

[30] R. L. Puurunen, J Appl Phys 2005, 97.

[31] P. Poodt, A. Lankhorst, F. Roozeboom, K. Spee, D. Maas, A. Vermeer, Adv Mater 2010, 22, 3564.

[32] M. Saliba, T. Matsui, K. Domanski, J.-Y. Seo, A. Ummadisingu, S. M. Zakeeruddin, J.-P. Correa-Baena, W. R. Tress, A. Abate, A. Hagfeldt, M. Grätzel, Science 2016.

[33] L. Liu, J. A. McLeod, R. Wang, P. Shen, S. Duhm, Appl Phys Lett 2015, 107, 061904.

[34] E. Mosconi, G. Grancini, C. Roldán-Carmona, P. Gratia, I. Zimmermann, M. K. Nazeeruddin, F. De Angelis, Chem Mater 2016, 28, 3612.

[35] S. Olthof, K. Meerholz, Scientific Reports 2017, 7, 40267.

[36] Q. Chen, H. Zhou, T.-B. Song, S. Luo, Z. Hong, H.-S. Duan, L. Dou, Y. Liu, Y. Yang, Nano Lett 2014, 14, 4158.

[37] J. Emara, T. Schnier, N. Pourdavoud, T. Riedl, K. Meerholz, S. Olthof, Adv Mater 2016, 28, 553.

[38] E. S. Thibau, A. Llanos, Z. H. Lu, Appl Phys Lett 2016, 108, 021602.

[39] C. Quarti, E. Mosconi, J. M. Ball, V. D'Innocenzo, C. Tao, S. Pathak, H. J. Snaith, A. Petrozza, F. De Angelis, Energ Environ Sci 2016, 9, 155.

[40] J. Endres, D. A. Egger, M. Kulbak, R. A. Kerner, L. Zhao, S. H. Silver, G. Hodes, B. P. Rand, D. Cahen, L. Kronik, A. Kahn, The Journal of Physical Chemistry Letters 2016, 7, 2722. 
[41] J. D. Servaites, M. A. Ratner, T. J. Marks, Energ Environ Sci 2011, 4, 4410.

[42] S. Dongaonkar, J. D. Servaites, G. M. Ford, S. Loser, J. Moore, R. M. Gelfand, H. Mohseni, H. W. Hillhouse, R. Agrawal, M. A. Ratner, T. J. Marks, M. S. Lundstrom, M. A. Alam, J Appl Phys 2010, 108, 124509.

[43] K. O. Brinkmann, J. Zhao, N. Pourdavoud, T. Becker, T. Hu, S. Olthof, K. Meerholz, L. Hoffmann, T. Gahlmann, R. Heiderhoff, M. F. Oszajca, N. A. Luechinger, D. Rogalla, Y. Chen, B. Cheng, T. Riedl, Nat Commun 2017, 8, 13938.

[44] W. Tress, K. Leo, M. Riede, Adv Funct Mater 2011, 21, 2140.

[45] S. Trost, K. Zilberberg, A. Behrendt, A. Polywka, P. Görrn, P. Reckers, J. Maibach, T. Mayer, T. Riedl, Advanced Energy Materials 2013, 3, 1437.

[46] D. Bartesaghi, I. d. C. Pérez, J. Kniepert, S. Roland, M. Turbiez, D. Neher, L. J. A. Koster, Nat Commun 2015, 6, 7083.

[47] J. Reinhardt, M. Grein, C. Bühler, M. Schubert, U. Würfel, Advanced Energy Materials 2014, 4, 1400081.

[48] A. Polywka, A. Vereshchaeva, T. Riedl, P. Görrn, Particle \& Particle Systems Characterization 2014, 31, 342.

[49] S. Trost, T. Becker, K. Zilberberg, A. Behrendt, A. Polywka, R. Heiderhoff, P. Görrn, T. Riedl, Scientific Reports 2015, 5, 7765.

[50] J. Yoon, H. Sung, G. Lee, W. Cho, N. Ahn, H. S. Jung, M. Choi, Energ Environ Sci 2017, 10, 337.

[51] Helmholtz-Zentrum Berlin für Materialien und Energie, Journal of large-scale research facilities 2016, 2, A49. 


\section{Supporting Information}

Table S1 Solar cell performance parameters for device based on the ITO-free transparent electrode $\mathrm{H}_{2} \mathrm{O}-\mathrm{SnO}_{\mathrm{x}} / \mathrm{Ag} / \mathrm{H}_{2} \mathrm{O}-\mathrm{SnO}_{\mathrm{x}}$ /ozone-SnO $\mathrm{S}_{\mathrm{x}}$ measured in forward and reverse direction with a scan rate of $100 \mathrm{mV} / \mathrm{s}$. The statics is based on 15 nominally identical devices. $J_{\mathrm{sc}}$ was derived from the EQE spectra. Best values are given in parentheses.

\begin{tabular}{ccccc}
\hline $\begin{array}{c}J / V \text { sweep } \\
\text { direction }\end{array}$ & $\begin{array}{c}J_{\mathrm{sc}} \\
{\left[\mathrm{mA} \mathrm{cm}^{-2}\right]}\end{array}$ & $\begin{array}{c}V_{\mathrm{oc}} \\
{[\mathrm{V}]}\end{array}$ & $\begin{array}{c}\text { FF } \\
{[\%]}\end{array}$ & $\begin{array}{c}\text { PCE } \\
{[\%]}\end{array}$ \\
\hline \multirow{2}{*}{ Reverse } & $16.4 \pm 0.5$ & $1.13 \pm 0.01$ & $52 \pm 2$ & $9.6 \pm 0.4$ \\
& $(17.1)$ & $(1.14)$ & $(55)$ & $(10.2)$ \\
\hline \multirow{2}{*}{ Forward } & $15.8 \pm 0.5$ & $1.11 \pm 0.01$ & $59 \pm 2$ & $10.3 \pm 0.4$ \\
& $(16.8)$ & $(1.14)$ & $(61)$ & $(11.0)$ \\
\hline
\end{tabular}

Table S2 Comparison of $\mathrm{MAPbI}_{3}$ perovskite cells based on non-ITO bottom electrodes. Note, in this comparison we deliberately did not consider cells based on fluorine doped tin-oxide (FTO) electrodes, which actually also would be In-free but require high temperature annealing.

\begin{tabular}{c|c|c|c|c|c}
\hline bottom electrode & $\begin{array}{c}J_{\mathrm{sc}} \\
{\left[\mathrm{mA} \mathrm{cm}^{-2}\right]}\end{array}$ & $\begin{array}{c}V_{\mathrm{oc}} \\
{[\mathrm{V}]}\end{array}$ & $\begin{array}{c}\mathrm{FF} \\
{[\%]}\end{array}$ & $\begin{array}{c}\text { PCE } \\
{[\%]}\end{array}$ & Ref. \\
\hline $\mathbf{M o O}_{3}$-decotated graphene & $\mathbf{2 1 . 7}$ & $\mathbf{1 . 0}$ & $\mathbf{7 8}$ & $\mathbf{1 6 . 8}$ & ${ }^{[1]}$ \\
\hline AgNWs/graphene-oxide & 13.78 & 0.94 & 71.3 & 9.23 & ${ }^{[2]}$ \\
\hline $\mathrm{Ag}$-mesh/PEDOT:PSS & 19.5 & 0.91 & 80 & 14.2 & ${ }^{[3]}$ \\
\hline AgNWs/F:ZnO & 12.2 & 0.685 & 39.5 & 3.29 & ${ }^{[4]}$ \\
\hline MPTMS SAM/Ag/MUTAB SAM & $\begin{array}{c}19.76^{\mathrm{a}} \\
17.23\end{array}$ & 1.00 & 76.57 & $\begin{array}{c}15.13^{\mathrm{a}} \\
12.93\end{array}$ & ${ }^{[5]}$ \\
\hline $\mathrm{SnO}_{\mathrm{x}} / \mathrm{Ag} / \mathrm{SnO}_{\mathrm{x}}$ & 16.4 & 1.11 & 61 & 11.0 & $\begin{array}{c}\text { this } \\
\text { work }\end{array}$ \\
\hline
\end{tabular}

${ }^{\mathrm{a}}$ with anti-reflective coating 

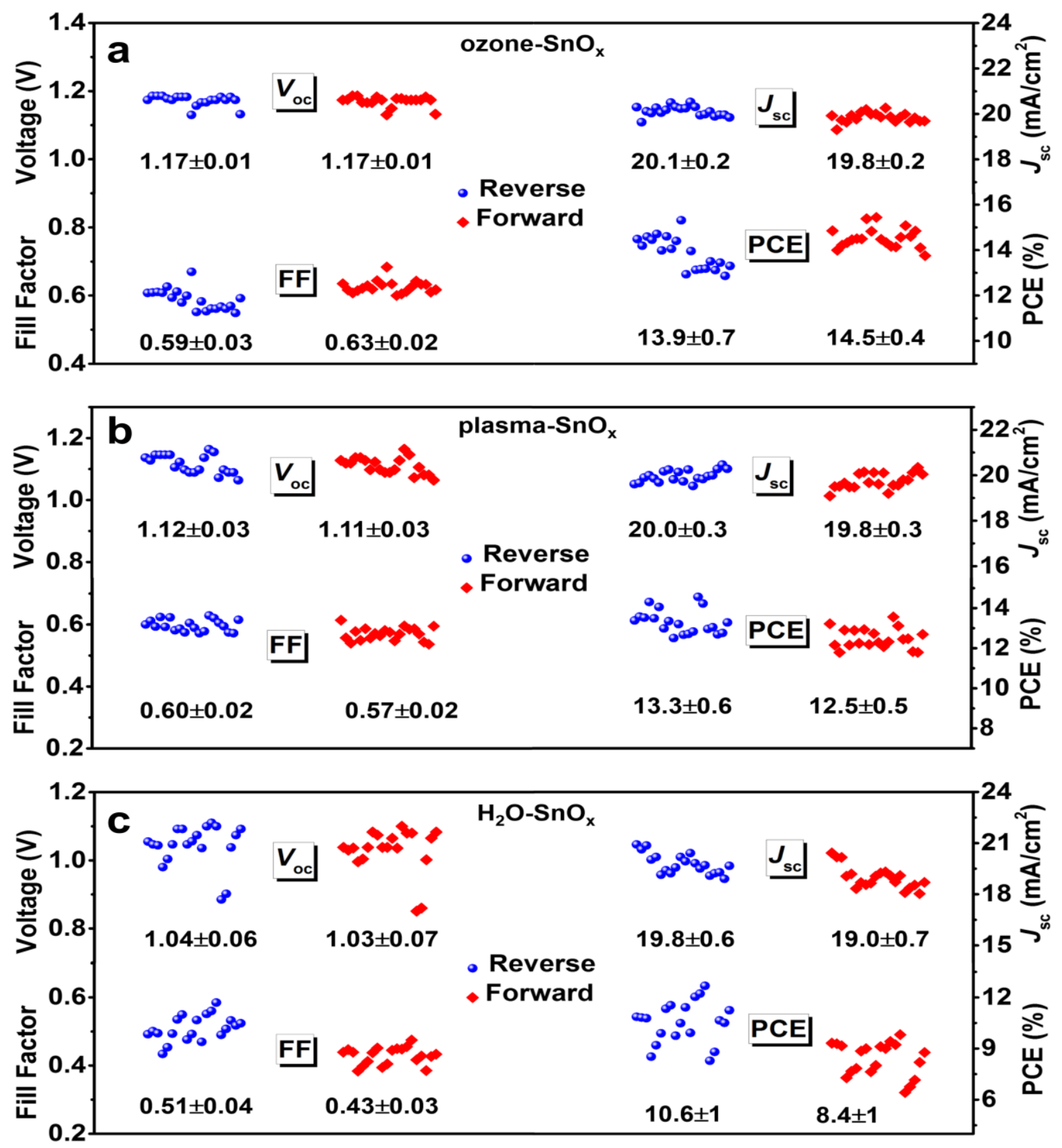

Figure S1 A graphical representation of the device characteristics of cells based on ozone$\mathrm{SnO}_{\mathrm{x}}$ (a), plasma-SnO $\mathrm{x}_{\mathrm{x}}$ (b), and $\mathrm{H}_{2} \mathrm{O}-\mathrm{SnO}_{\mathrm{x}}$ (c) as EEL. For each configuration 20 devices have been measured in forward and reverse sweep at a scan rate of $100 \mathrm{mV} / \mathrm{s}$. 

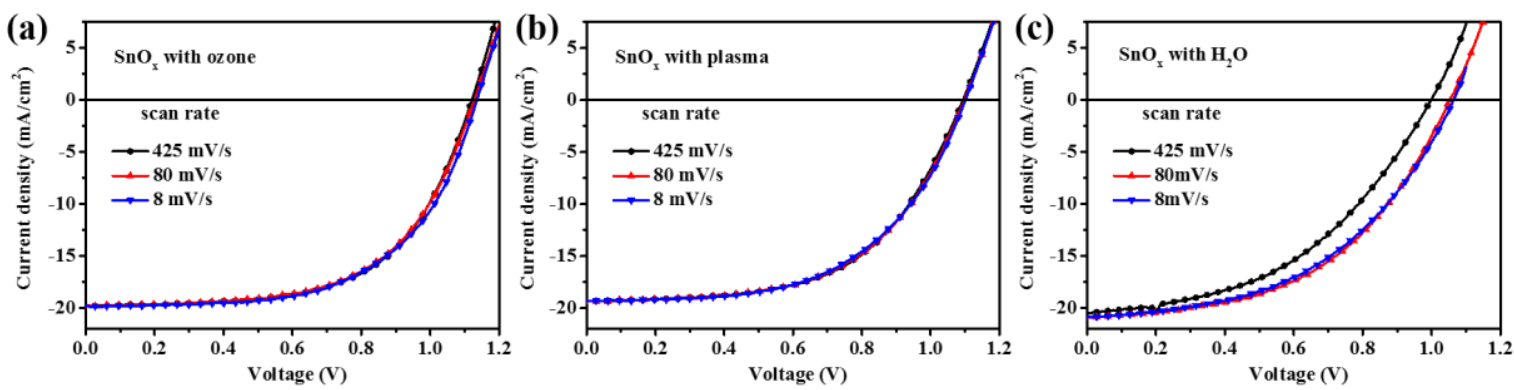

Figure S2 Scan rate dependence of the $J-V$ characteristics of ozone- $\mathrm{SnO}_{\mathrm{x}}$ (a), plasma-SnO $\mathrm{x}_{\mathrm{x}}$ (b), and $\mathrm{H}_{2} \mathrm{O}-\mathrm{SnO}_{\mathrm{x}}$ (c) based devices in reverse direction.
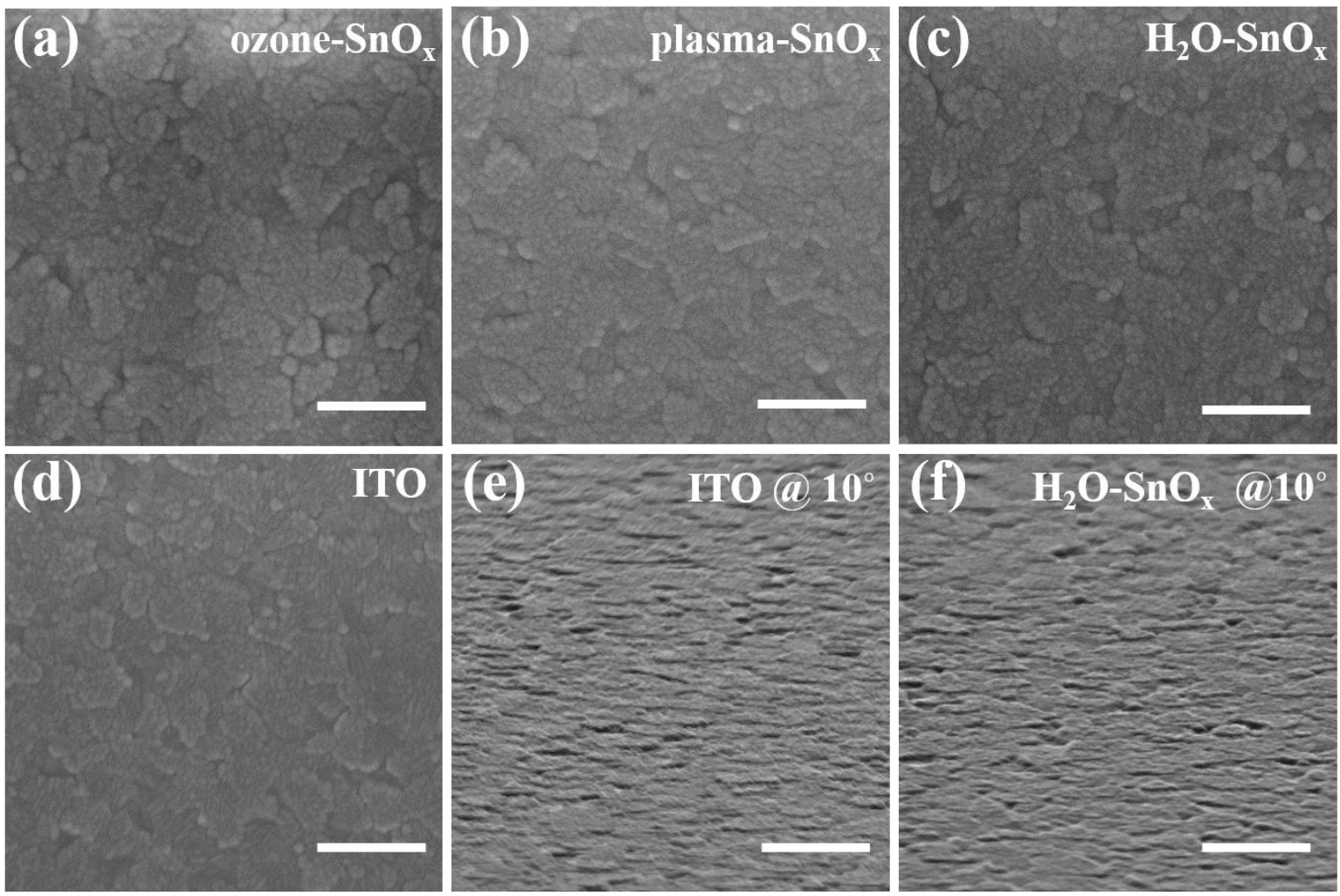

Figure S3 Plan view SEM images of $20 \mathrm{~nm}$ thick ozone-SnO $\mathrm{S}_{\mathrm{x}}$ (a) plasma-SnO $\mathrm{S}_{\mathrm{x}}$ (b) and $\mathrm{H}_{2} \mathrm{O}-$ $\mathrm{SnO}_{\mathrm{x}}$ (c) layers on top of ITO. The ITO layer on glass is shown as a reference (d). In parts (e) and (f) the ITO and $\mathrm{H}_{2} \mathrm{O}-\mathrm{SnO}_{\mathrm{x}}$ on ITO samples have been studied under an angle of $10^{\circ}$. The bar in the micrographs is $500 \mathrm{~nm}$. 

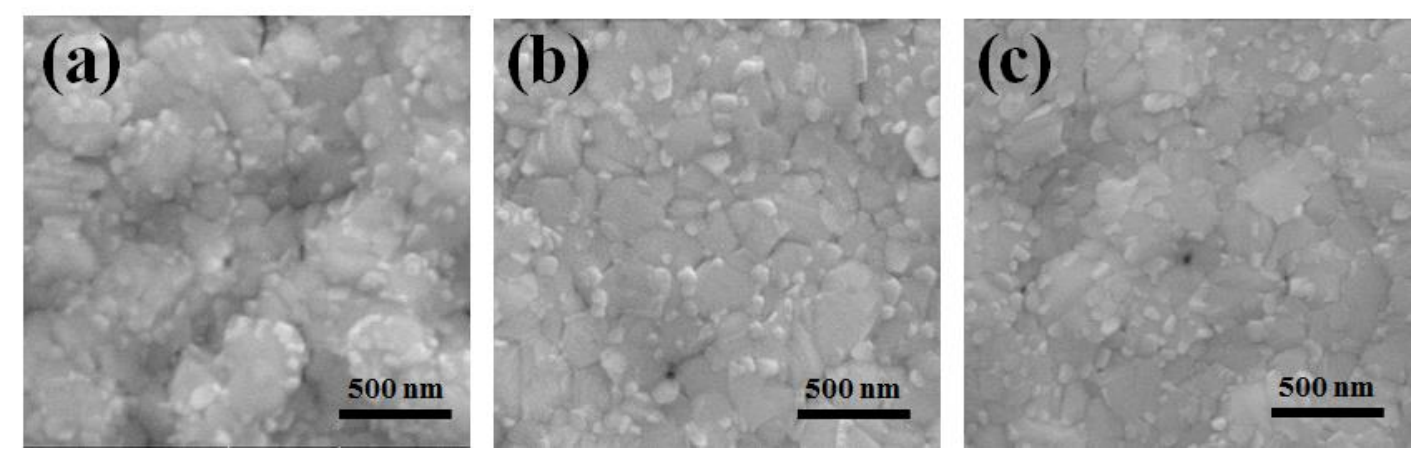

Figure S4 SEM images of the perovskite layer deposited on ozone-SnO $\mathrm{x}_{\mathrm{x}}$ (a) plasma-SnO $\mathrm{x}_{\mathrm{x}}$ (b) and $\mathrm{H}_{2} \mathrm{O}-\mathrm{SnO}_{\mathrm{x}}$ (c).
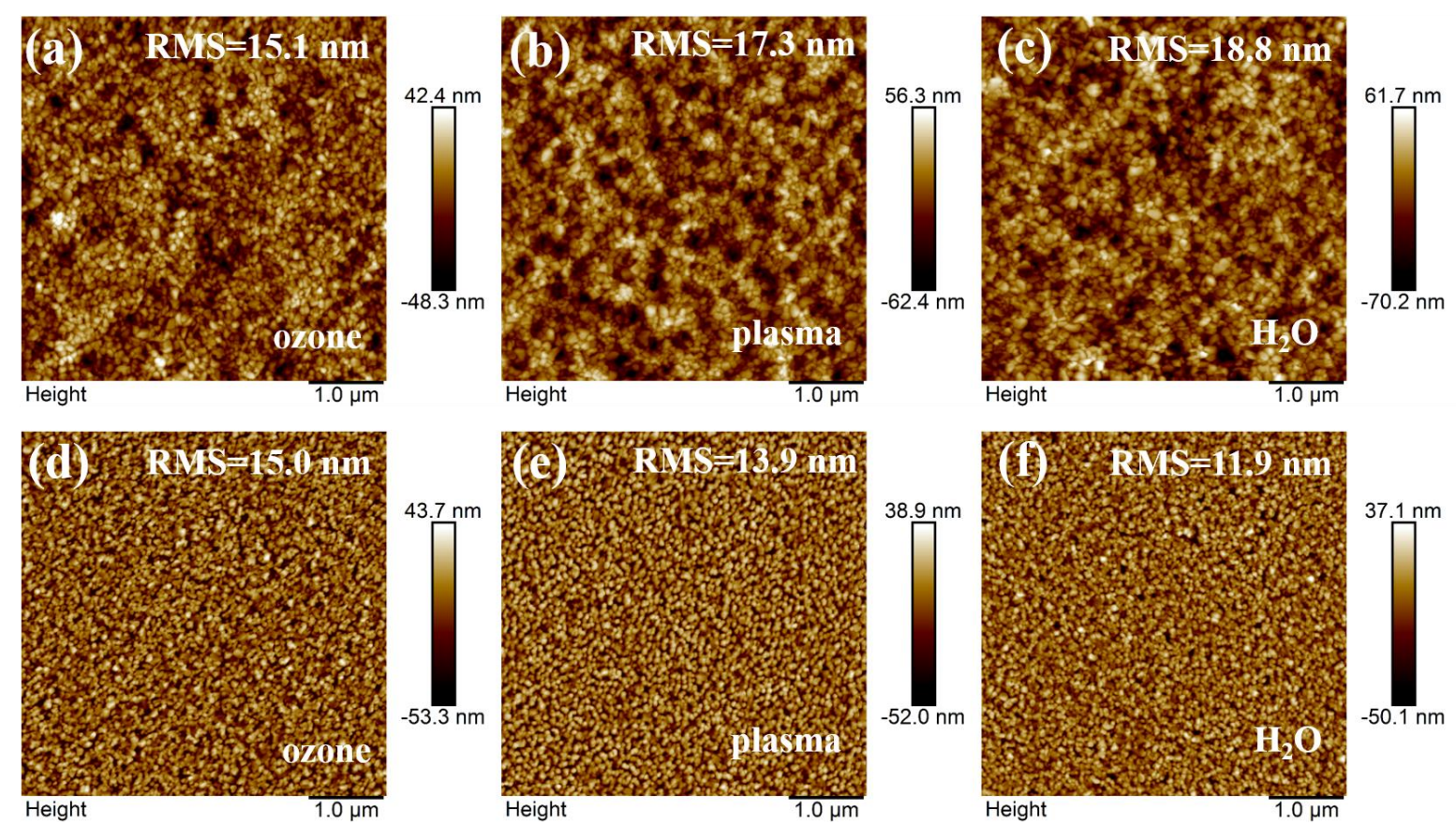

Figure S5 AFM images of the normal perovskite layer (a-c) and ultrathin perovskite layer (df) deposited on ozone-SnO ${ }_{x}(a, d)$ plasma- $\mathrm{SnO}_{x}(b, e)$ and $\mathrm{H}_{2} \mathrm{O}-\mathrm{SnO}_{\mathrm{x}}(\mathrm{c}, \mathrm{f})$. The root-meansquare (RMS) roughness is shown as well.

As shown in Figure S4, the SEM images of the three perovskite films are similar. The shape and size of the crystal grains are very similar and do not point to a strikingly different growth of the perovskite on top of the various $\mathrm{SnO}_{\mathrm{x}}$ layers. For the AFM results (Figure S5), the perovskite films present a relatively smooth surface with a roughness in the range of 15-18.8 $\mathrm{nm}(\mathrm{rms})$. 

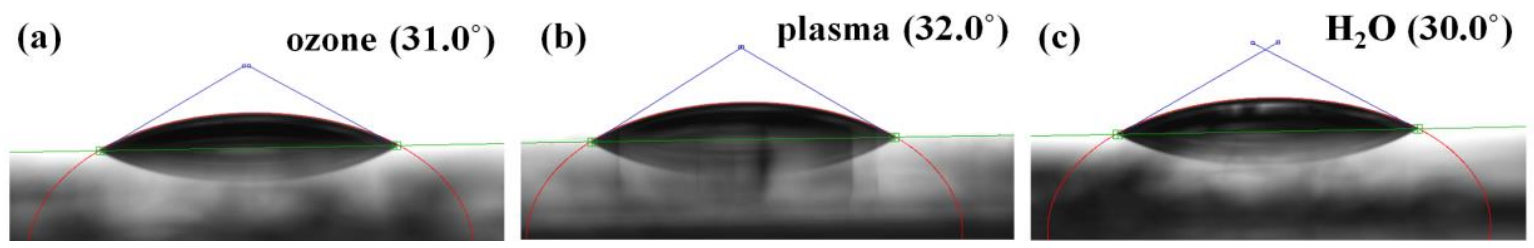

Figure S6 Images of diiodomethane droplets on ozone-SnO ${ }_{x}$ (a) plasma-SnO $\mathrm{S}_{\mathrm{x}}$ (b) and $\mathrm{H}_{2} \mathrm{O}-$ $\mathrm{SnO}_{\mathrm{x}}(\mathrm{c})$.
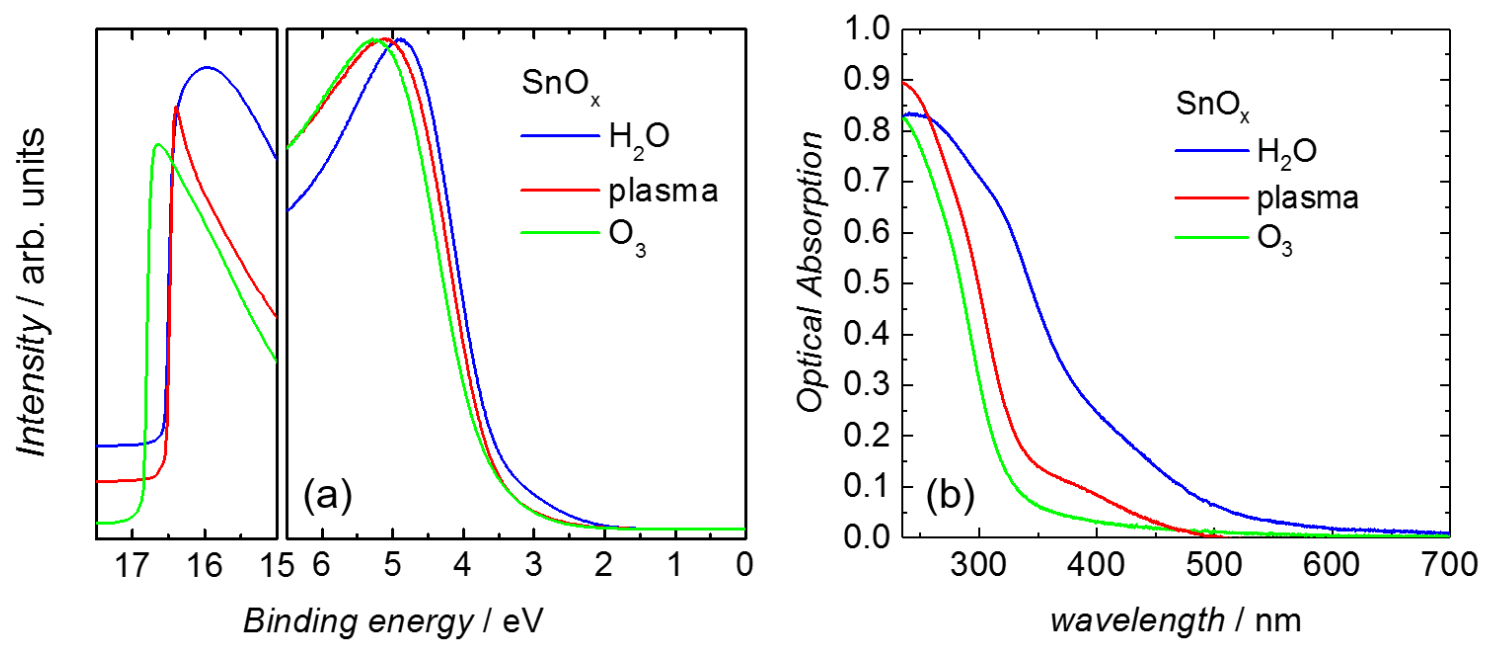

Figure S7 UPS spectra (a) and optical absorption spectra (b) for the different $\mathrm{SnO}_{\mathrm{x}}$ EELs.
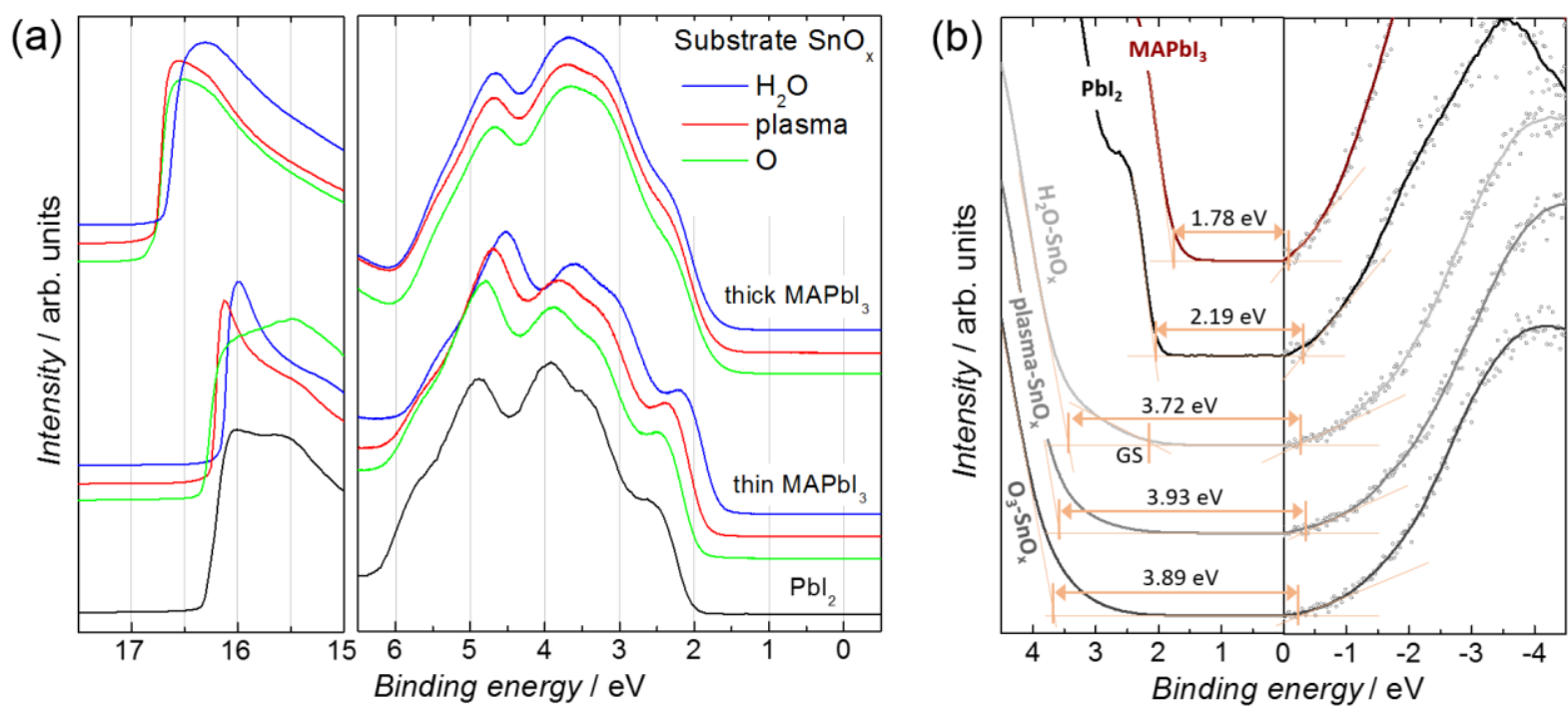

Figure S8 Photoelectron spectroscopy measurements that are used to derive the energy level diagram in Figure 3. (a) UPS measurements of the thin and thick perovskite layers as well as a comparative measurement of a $\mathrm{PbI}_{2}$ layer to show the similarity in density of state to the thin $\mathrm{MAPbI}_{3}$ film. (b) Combined direct and inverse photoemission spectroscopy measurements (UPS/IESP) of the three $\mathrm{SnO}_{\mathrm{x}}$ substrates as well as $\mathrm{PbI}_{2}$ and $\mathrm{MAPbI}_{3}$ from which the bandgaps are deduced. 

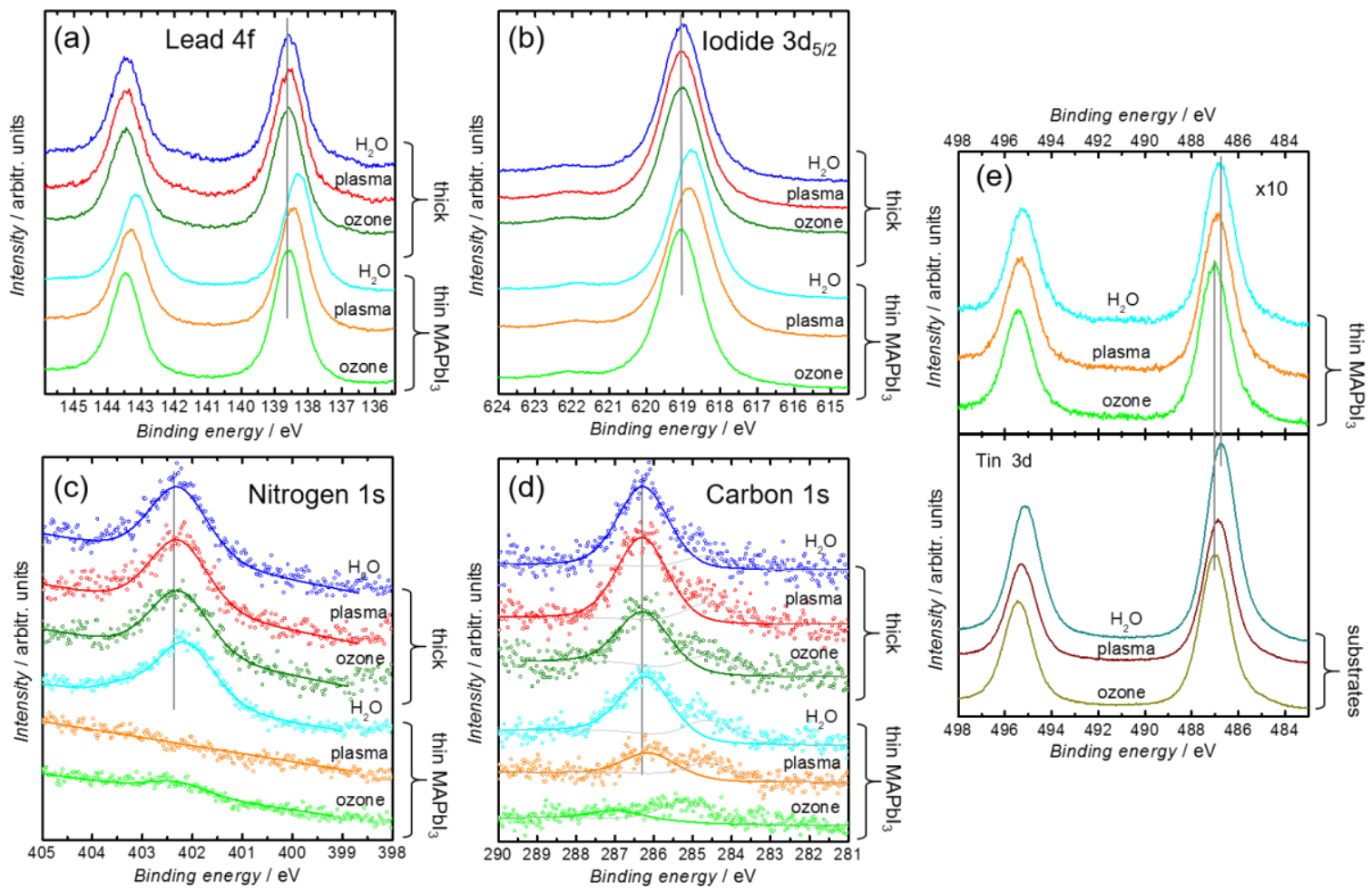

Figure S9 (a-d) Overview over the XPS core level measurements of the thin and thick perovskite layers; differences in energetic position for the thin films, as discussed for the UPS spectra, can be observed here as well. Furthermore, (c) and (d) show the lack of $\mathrm{N}$ and $\mathrm{C}$ signal for the thin perovskite layers on top of the ozone and plasma $\mathrm{SnO}_{\mathrm{x}}$. (e) Sn3d core level spectra for the bare substrates (bottom) as well as the substrates covered by a thin perovskite layer showing that there is no significant change in the Sn3d core level binding energy, so the band bending in the $\mathrm{SnO}_{\mathrm{x}}$ substrate is not affected by the deposition of the perovskite.

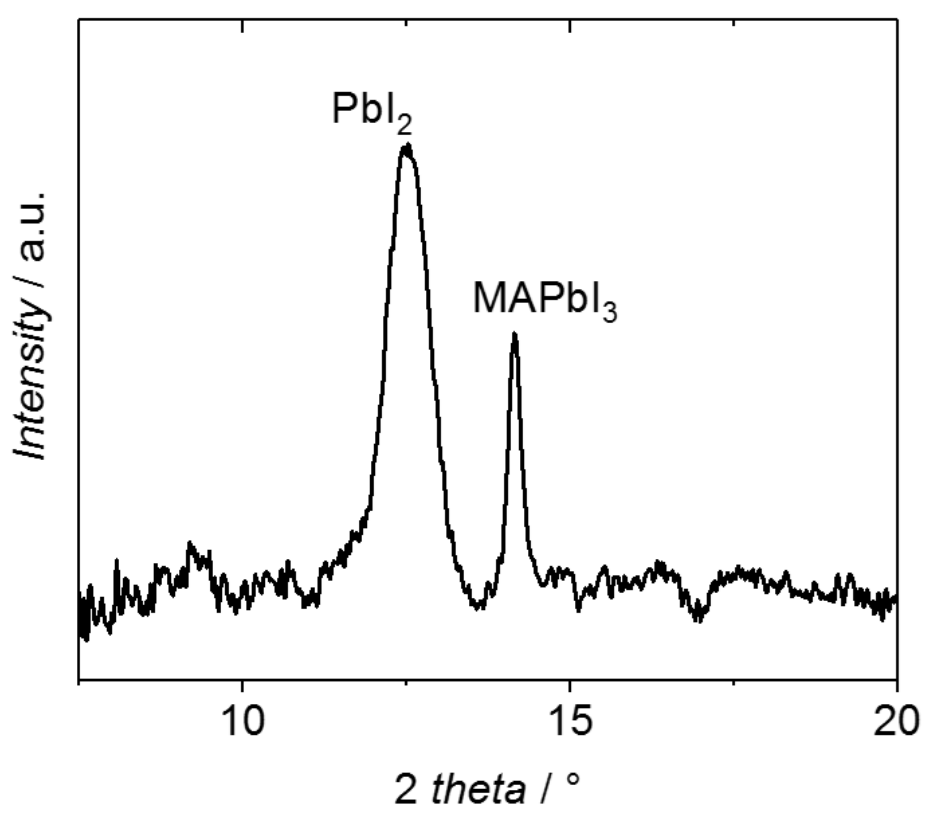

Figure S10 GIWAXS pattern of a thin $\mathrm{MAPbI}_{3}$ layer (thickness $<10 \mathrm{~nm}$ ) on top of $\mathrm{H}_{2} \mathrm{O}-$ $\mathrm{SnO}_{\mathrm{x}}$, revealing much higher ratio of $\mathrm{PbI}_{2}$ to $\mathrm{MAPbI}_{3}$ than was observed for thick layers. 
(a)

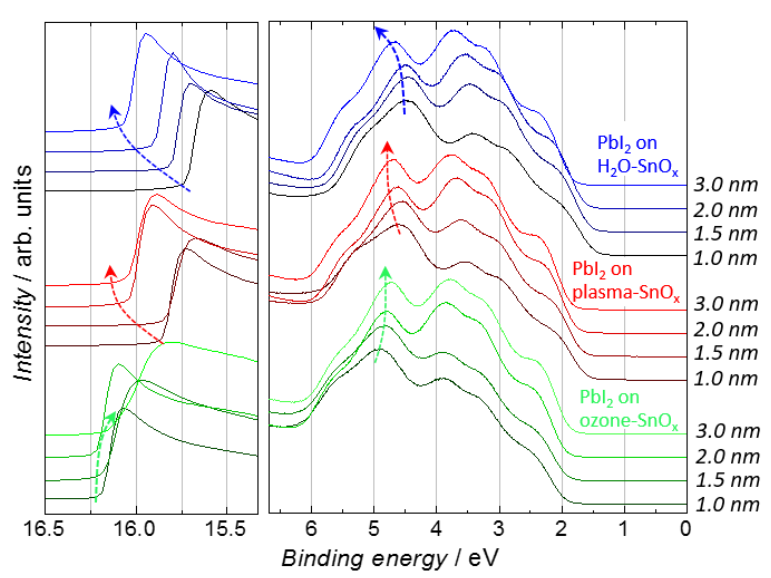

(b)

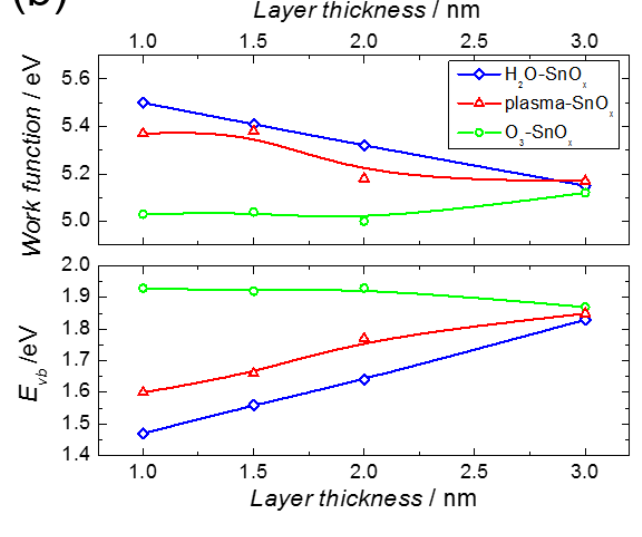

(c)

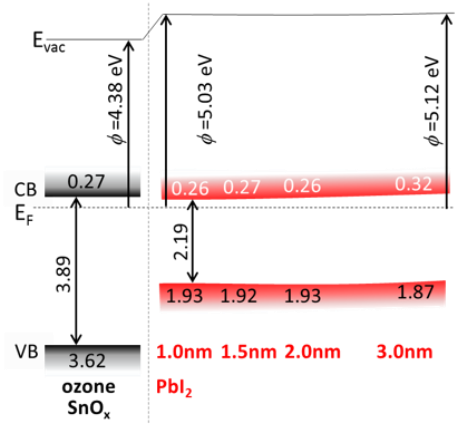

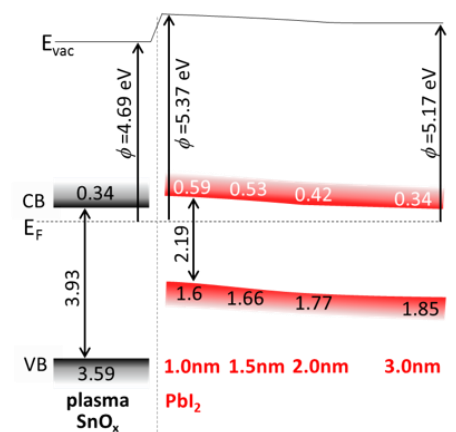

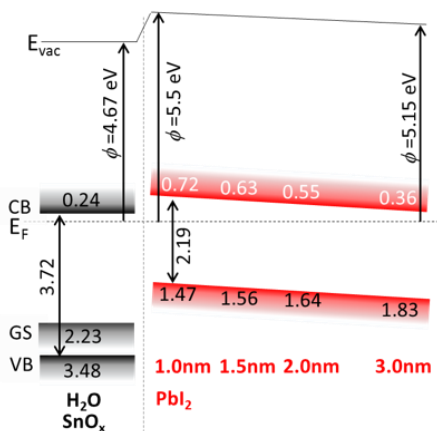

Figure S11 UPS measurements of thermally evaporated $\mathrm{PbI}_{2}$ with step-wise increased thickness (from $1 \mathrm{~nm}$ to $3 \mathrm{~nm}$ ) on top of the different $\mathrm{SnO}_{\mathrm{x}}$ variants (a). Variation of the work function and valence band position of the $\mathrm{PbI}_{2}$ depending on its thickness (b). Derived energy level alignment of $\mathrm{PbI}_{2}$ on top the different $\mathrm{SnO}_{x}$ electron extraction layers.

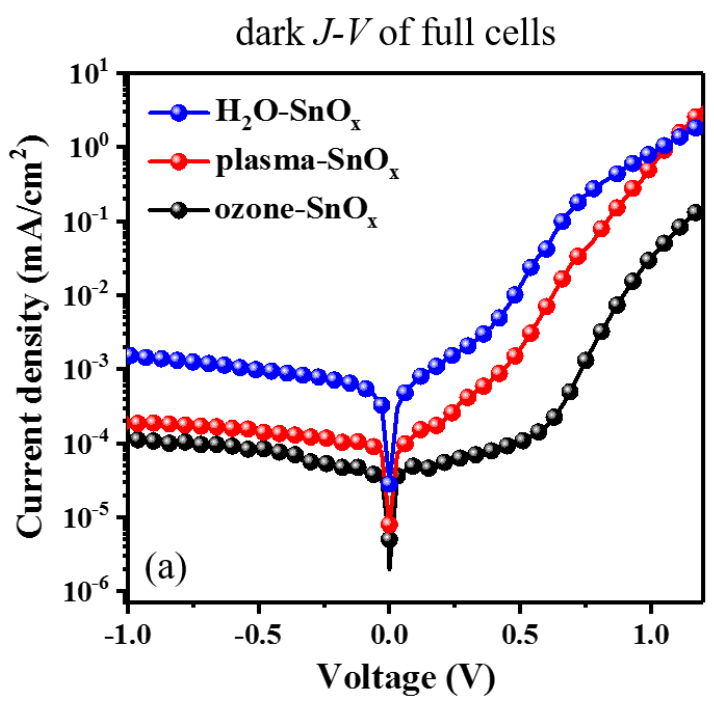

dark $J-V$ of electron-only devices

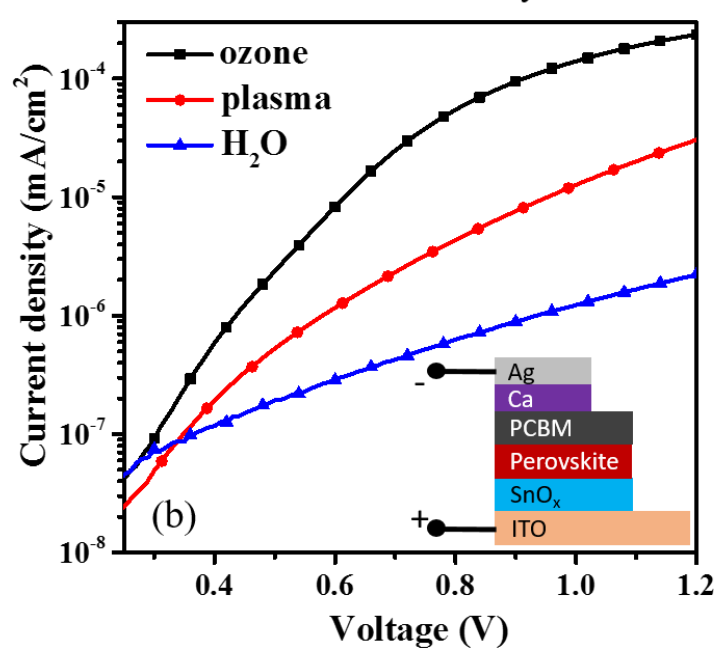

Figure S12 $J$ - $V$ characteristics in dark of full cells (a), and of electron-only devices (b) based on different $\mathrm{SnO}_{\mathrm{x}}$. The inset shows the unipolar device structure and the biasing scheme. 


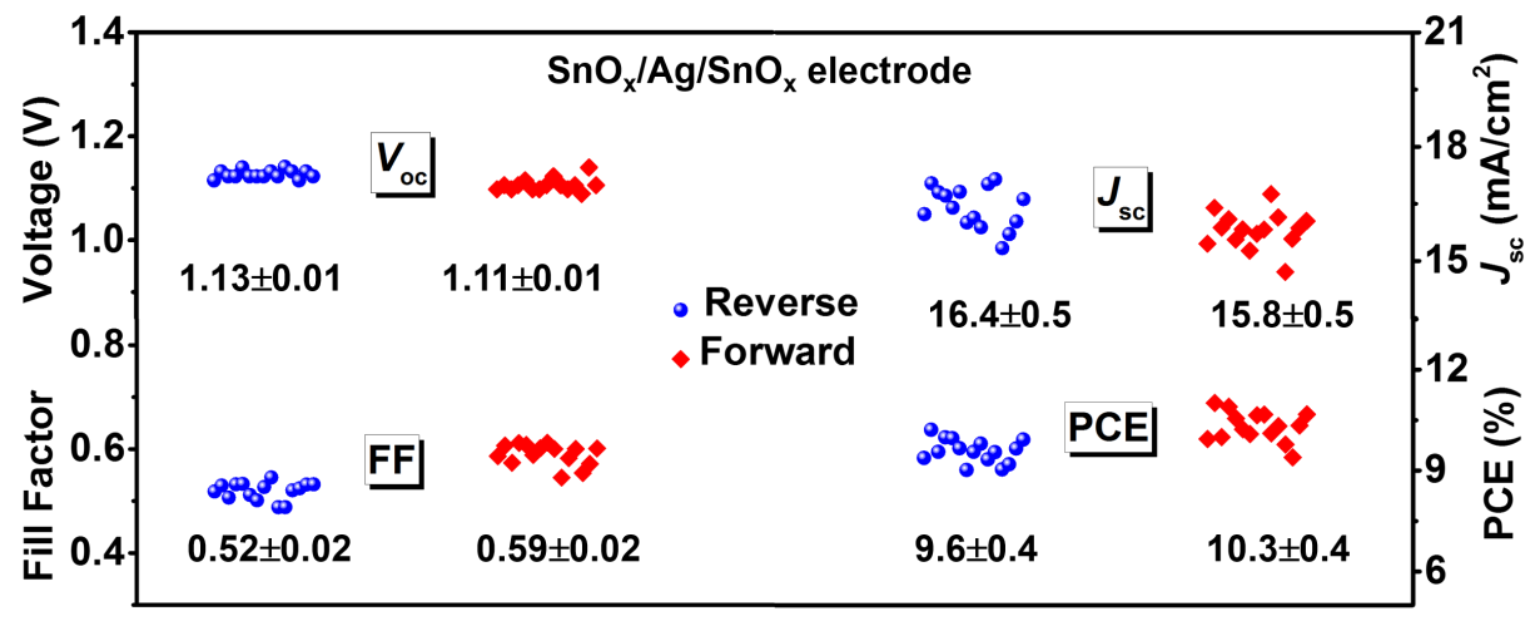

Figure S13 A graphical representation of the device characteristics of cells based on $\mathrm{SnO}_{\mathrm{x}} / \mathrm{Ag} / \mathrm{SnO}_{\mathrm{x}}$ bottom electrodes. 15 nominally identical devices have been measured in forward and reverse sweep at a scan rate of $100 \mathrm{mV} / \mathrm{s}$.

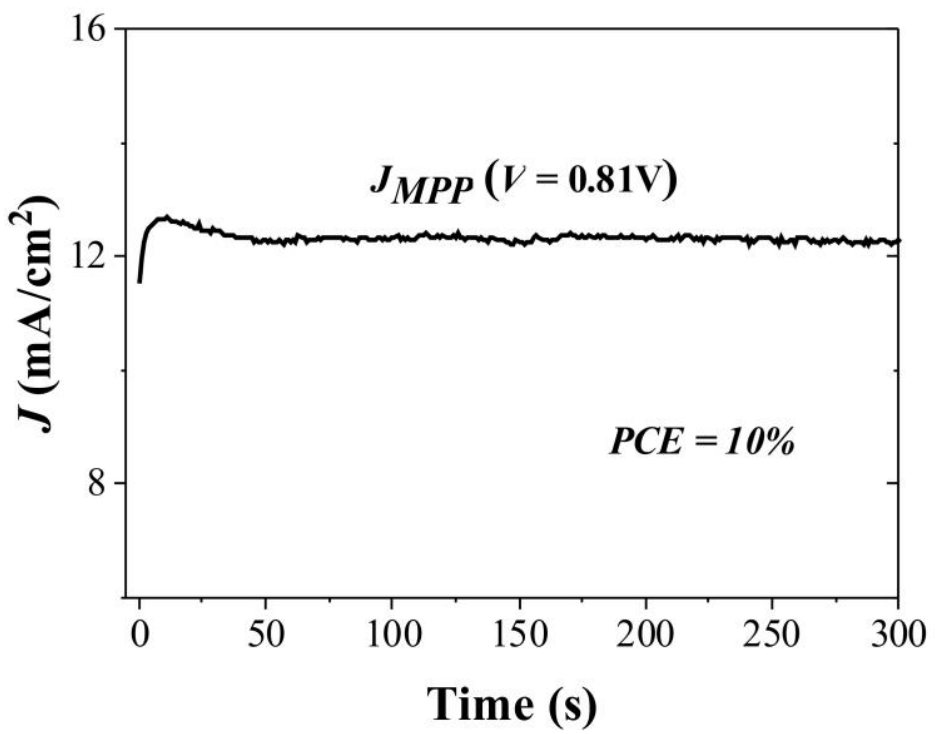

Figure S14 Current density in the maximum power point vs. time for a device based on a $\mathrm{SnO}_{\mathrm{x}} / \mathrm{Ag} / \mathrm{SnO}_{\mathrm{x}}$ bottom electrode.

[1] J. Yoon, H. Sung, G. Lee, W. Cho, N. Ahn, H. S. Jung, M. Choi, Energ Environ Sci $2017,10,337$.

[2] H. Lu, J. Sun, H. Zhang, S. Lu, W. C. H. Choy, Nanoscale 2016, 8, 5946.

[3] Y. Li, L. Meng, Y. M. Yang, G. Xu, Z. Hong, Q. Chen, J. You, G. Li, Y. Yang, Y. Li, Nat Commun 2016, 7, 10214.

[4] J. Han, S. Yuan, L. Liu, X. Qiu, H. Gong, X. Yang, C. Li, Y. Hao, B. Cao, J. Mater. Chem. A 2015, 3, 5375.

[5] C.-Y. Chang, Y.-C. Chang, W.-K. Huang, W.-C. Liao, H. Wang, C. Yeh, B.-C. Tsai, Y.C. Huang, C.-S. Tsao, J. Mater. Chem. A 2016, 4, 7903. 
